
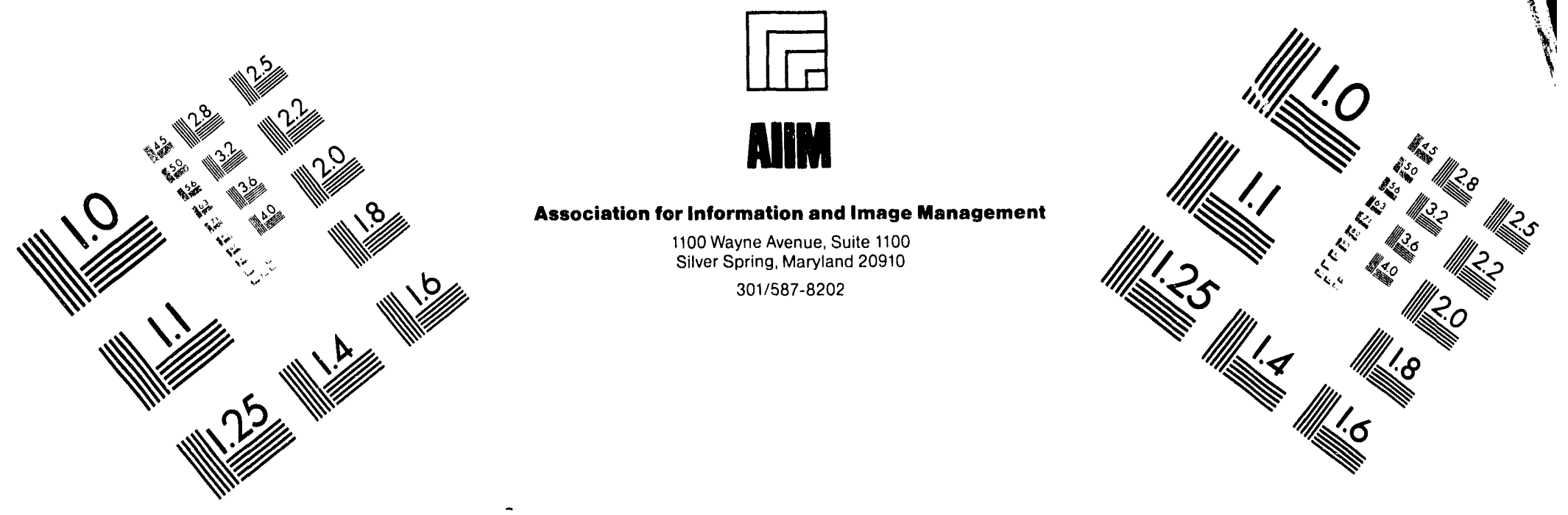

Centimeter

$\begin{array}{llllllllllllllll}1 & 2 & 3 & 4 & 5 & 6 & 7 & 8 & 9 & 10 & 11 & 12 & 13 & 14 & 15 & 15\end{array}$

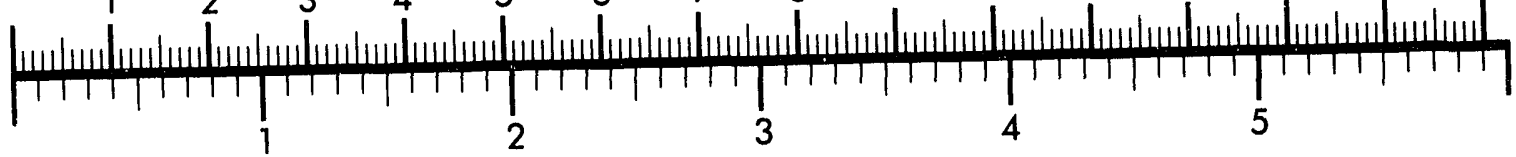
Inches
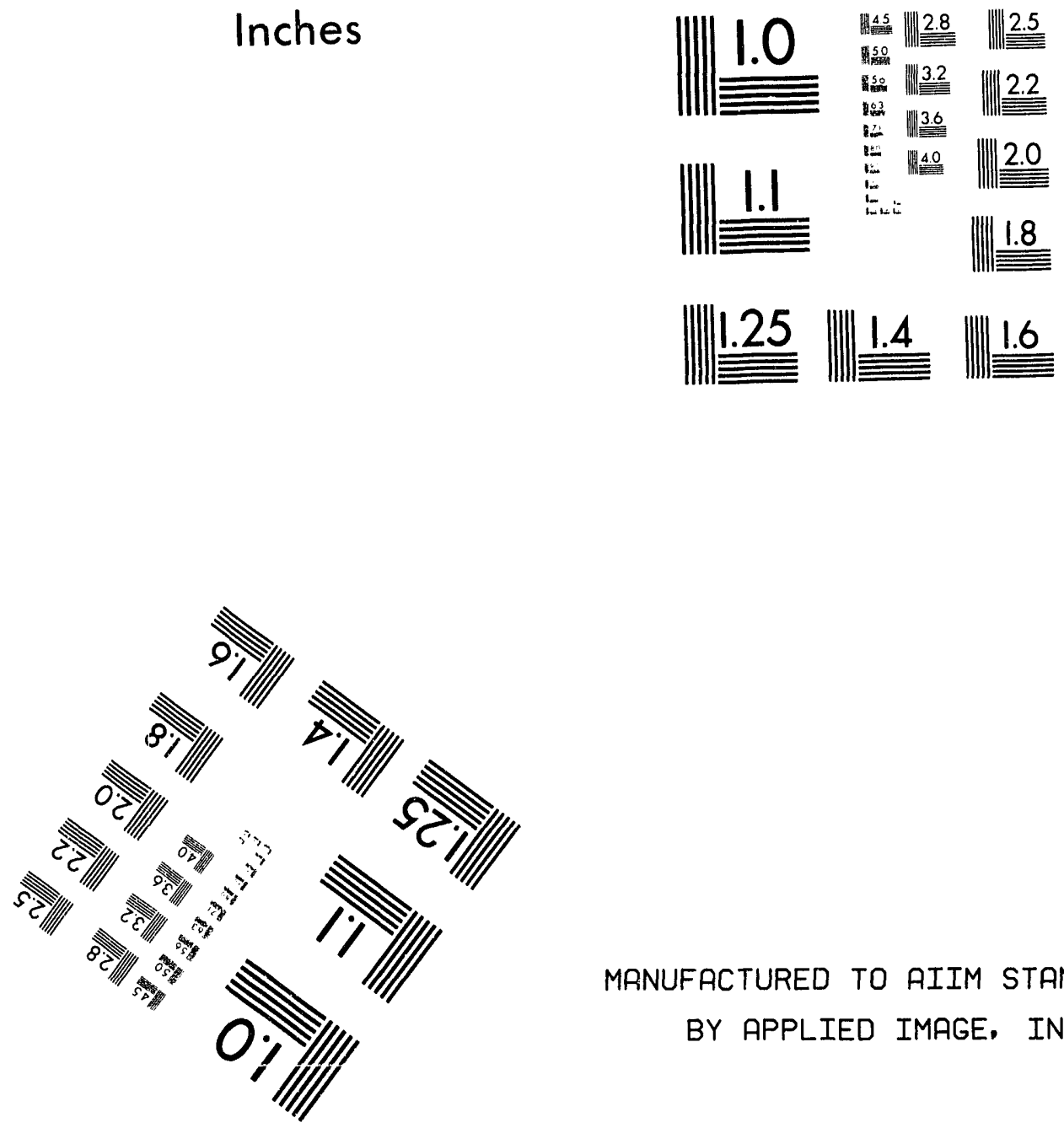

MRNUFACTURED TO AIIM STANDARDS

BY APPLIED IMAGE, INC.

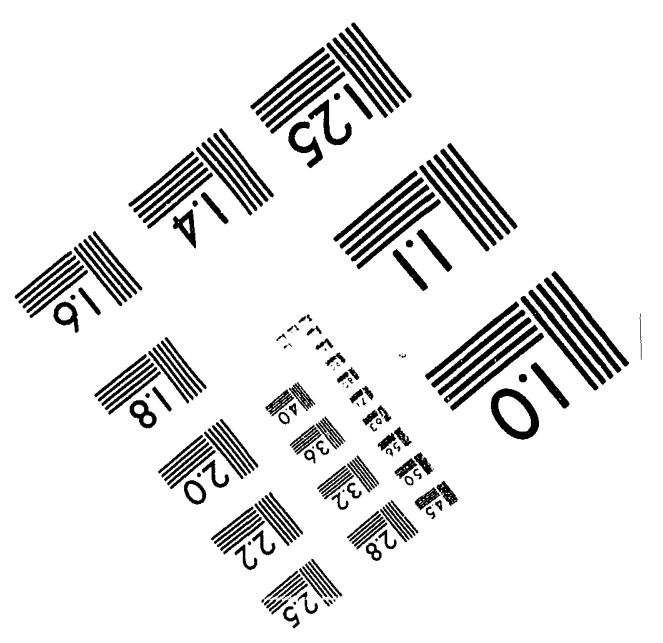



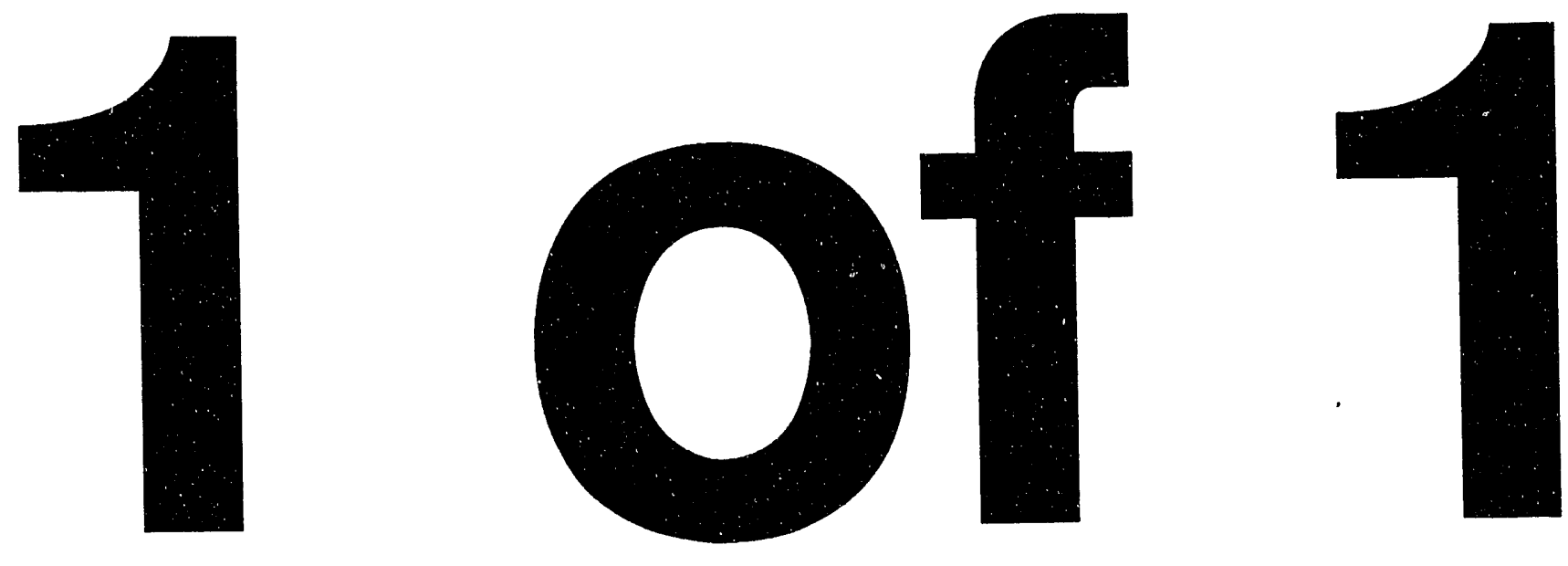


\title{
Nonradioactive Air Emissions Notice of Construction for the Waste Receiving and Processing Facility
}

Date Published

February 1993

\author{
DISCLAIMER
}

This report was prepared as an account of work sponsored by an agency of the United States Government. Neither the United States Government nor any agency thereof, nor any of their employees, makes any warranty, express or implied, or assumes any legal liability or responsibility for the accuracy, completeness, or usefulness of any information, apparatus, product, or process disclosed, or represents that its use would not infringe privately owned rights. Reference herein to any specific commercial product, process, or service by trade name, trademark, manufacturer, or otherwise does not necessarily constitute or imply its endorsement, recommendation, or favoring by the United States Government or any agency thereof. The views and opinions of authors expressed herein do not necessarily state or reflect those of the United States Government or any agency thereof.

Prepared for the U.S. Department of Energy Office of Environmental Restoration and Waste Management

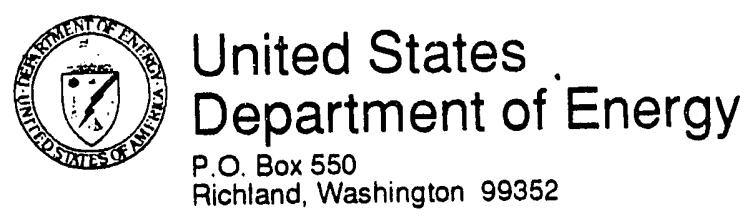




\section{CONTENTS}

1.0 DESCRIPTION OF THE PROPOSED SOURCE . . . . . . . . . . . . . . . . . 1-1

1.1 FUNCTION OF FACILITY . . . . . . . . . . . . . . . . . . . . 1-1

1.2 LOCATION OF FACILITY . . . . . . . . . . . . . . . . . . 1-1

1.3 DESCRIPTION OF FACILITY . . . . . . . . . . . . . . . . . . . . . . . $1-1$

2.0 OPERATIONS AND PROCESS DESCRIPTIONS . . . . . . . . . . . . . 2-1

2.1 DESCRIPTION OF OPERATIONS . . . . . . . . . . . . . . . 2-1

2.1.1 Shipping and Receiving .. . . . . . . . . . . . 2-3

2.1.2 Non-Destructive Examination/Non-Destructive Assay Systems .................. 2-3

2.1.3 Processing Area . . . . . . . . . . . . . . . . 2-5

2.1.4 Ancillary Support Areas .............. . 2-9

2.2 DESCRIPTION OF VENTILATION SYSTEMS . . . . . . . . . . . . . 2-9

2.2.1 Exhaust Stack ................. . 2-10

2.2.2 Miscellaneous Vents ............... . 2-13

2.3 OPERATING MODE ..................... . . 2-14

2.4 SOURCES OF EMISSIONS . . . . . . . . . . . . . . . . 2-14

2.5 EMISSIONS CONTROL TECHNOLOGY . . . . . . . . . . . . . 2-16

3.0 TOXIC AIR POLLUTANT EMISSION ESTIMATIONS . . . . . . . . . . . . . . . 3-1

3.1 ESTIMATED TOXIC SUBSTANCE CONTENT OF THE WASTES . . . . . . . . . . 3-1

3.1.1 Leaded Materials . . . . . . . . . . . . . . . . . 3-1

3.1.2 Fluorescent Light Tubes . . . . . . . . . . . . . . . . 3-1

3.1.3 Aerosol Cans . . . . . . . . . . . . . . . . . . 3-1

3.1.4 Miscellaneous Liquids, Lab Packs,
and Scintillation Vials . . . . . . . . . . . . 3-3

3.2 ANTICIPATED TOXIC AIR POLLUTANT EMISSIONS . . . . . . . . . . . . . $3-4$

3.2.1 Annual Average Emission Rate Assumptions . . . . . . . . 3-4

3.2.2 Peak Daily Emission Rate Assumptions . . . . . . . . . . 3-5

3.2.3 Uncontrolled Releases from Zone 1 Gloveboxes.... . . 3-5

3.2.4 Fugitive Emissions ... . . . . . . . . . . . . . . 3-5

3.3 ABATED PARTICULATE TOXIC AIR POLLUTANT EMISSIONS . . . . . . . 3-6

4.0 AIR QUALITY IMPACT ANALYSIS ................. . . . 4-1

4.1 MODELING METHODOLOGY ..................... . . $4-1$

4.2 METEOROLOGICAL DATA .................... . . . 4-2

4.3 MODEL RESULTS ....................... . . . . 4-2

5.0 BEST AVAILABLE CONTROL TECHNOLOGY FOR TOXICS ASSESSMENT . . . . . . 5-1

6.0 REFERENCES .......................... . . 6-1

APPENDIX

A CALCULATONS FOR EVAPORATIVE EMISSION RATES . . . . . . . . . . . A-1 


\section{LIST OF FIGURES}

1-1 Location of Waste Receiving and Processing Module 1 Facility within Hanford Site ... . . . . . . . . . . . . . . 1-2

1-2 Location of Waste Receiving and Processing Module 1 Facility in 200 West Area .................... . . . . . . . . . . .

2-1 Waste Receiving and Processing Module 1 Facility Floor Plan . . . 2-2

2-2 Waste Receiving and Processing Module 1 Facility Process Flow Diagram ...................... . . 2-4

2-3 Flow Diagram Through Transuranic Gloveboxes . . . . . . . . . 2-6

2-4 Flow Diagram Through Low-Level Waste Gloveboxes . . . . . . . 2-7

2-5 Exhaust Stack ....................... 2-11

2-6 Schematic of Zone I and Zone II Ventilation System . . . . . . . 2-12

\section{LIST OF TABLES}

2-1 Estimated Toxic Substance Contents of Drums to be Processed in Waste Receiving and Processing Module 1 Facility . . . . . . 2-15

3-1 Estimated Emissions from Zone I and Restricted Waste Management Gloveboxes...................... . . . 3-2

3-2 Estimated Volatile Organic Compound Fmissions from Indoor Drum Storage (Based on Indoor Storage of 260 Closed Drums) . . . . . . 3-6

4-1 Maximum Toxic Air Pollutant Ambient Concentrations for the Waste Receiving and Processing Module 1 Facility Emissions...... . 4-3 


\section{ACRONYMS}

$\begin{array}{ll}\text { ASIL } & \text { Acceptable Source Impact Level } \\ \text { CFC } & \text { chlorinated fluorocarbons } \\ \text { CH } & \text { contact handled } \\ \text { CVOC } & \text { carcinogenic volatile organic carbons } \\ \text { EPA } & \text { U.S. Environmental Protection Agency } \\ \text { HEPA } & \text { high efficiency particulate air } \\ \text { HVAC } & \text { heating, ventilation, and air conditioning } \\ \text { LLMW } & \text { low-level mixed waste } \\ \text { LLW } & \text { low-level waste } \\ \text { MTBK } & \text { methyl isobutyl ketone } \\ \text { NCVOC } & \text { noncarcinogenic volatile organic carbons } \\ \text { NDA } & \text { nondestructive analysis } \\ \text { NDE } & \text { nondestructive evaluation } \\ \text { PFP } & \text { Plutonium Finishing Plant } \\ \text { RTR } & \text { real time radiography } \\ \text { RWM } & \text { Restricted Waste Management } \\ \text { TAP } & \text { toxic air pollutants } \\ \text { TBACT } & \text { Best Available Control Technology for Toxics } \\ \text { TRU } & \text { transuranic } \\ \text { VOC } & \text { volatile organic carbons } \\ \text { WIPP } & \text { Waste Isolation Pilot Plant } \\ \text { WRAP } & \text { Waste Receiving and Processing } \\ - & \end{array}$


DOE/RL 93-18, Rev. 0

This page intentionally left blank. 


\section{NONRADIOACTIVE AIR EMISSIONS NOTICE OF CONSTRUCTION FOR THE WASTE RECEIVING AND PROCESSING FACILITY}

\subsection{DESCRIPTION OF THE PROPOSED SOURCE}

The following section describes the proposed source.

\subsection{FUNCTION OF FACILITY}

The mission of the Waste Receiving And Processing (WRAP) Module 1 facility (also referred to as WRAP 1) is to examine, assay, characterize, treat, and repackage solid radioactive and mixed waste to enable permanent disposal of the wastes in accordance with all applicable regulations. WRAP 1 will contain equipment and facilities necessary for non-destructive examination (NDE) of wastes and to perform a non-destructive examination assay (NDA) of the total radionuclide content of the wastes, without opening the outer container (e.g., 55-gal drum). WRAP 1 will also be equipped to open drums which do not meet waste acceptance and shipping criteria, and to perform limited physical treatment of the wastes to ensure that storage, shipping, and disposal criteria are met.

\subsection{LOCATION OF FACILITY}

The WRAP 1 facility will be located on the U.S. Department of Energy Hanford Site, which is located northwest of Richland, Washington, as shown on Figure 1-1. The WRAP 1 facility will be housed in the new 2336-W Building which will be located in the 200 West Area of Hanford, south of 23rd Street and west of Dayton Avenue as shown in Figure 1-2.

\subsection{DESCRIPTION OF FACILITY}

WRAP 1 will be housed in a new $51,300 \mathrm{ft}^{2}$ metal building consisting of pre-insulated, pre-finished metal, interlocking roof and wall sandwich panels. WRAP 1 will provide waste handling areas, support areas, mechanical areas, electrical areas, Heating, Ventilation, and Air Conditioning (HVAC) equipment, and administrative areas all located on the 43,700 $\mathrm{ft}^{2}$ main floor; with a control room, computer room, and the non-radiological HVAC equipment located on the $7,600 \mathrm{ft}^{2}$ second floor. 
Figure 1-1. Location of Waste Receiving and Processing Module 1 Facility within Hanford Site.

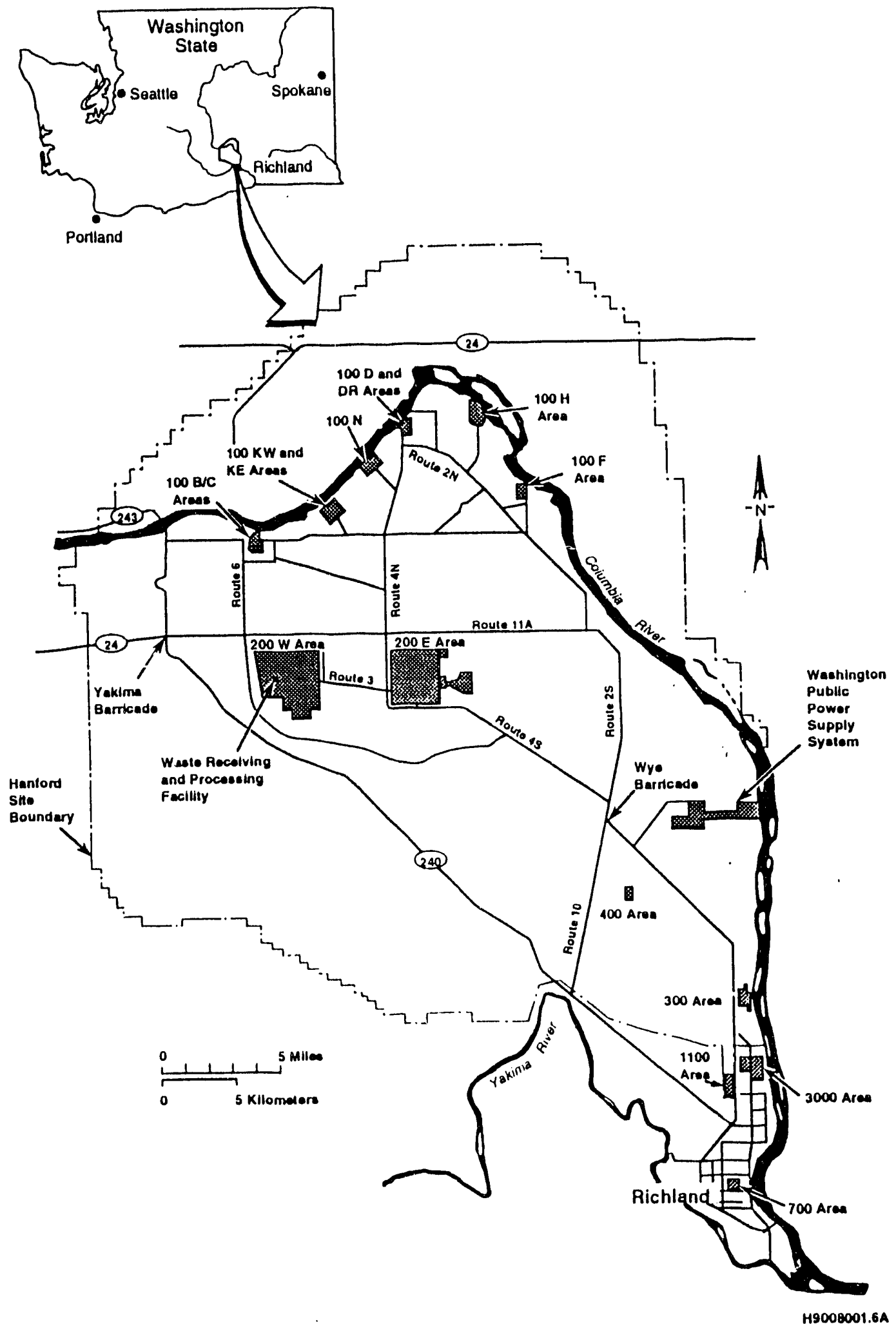


Figure 1-2. Location of Waste Receiving and Processing Module 1 Facility in 200 West Area.

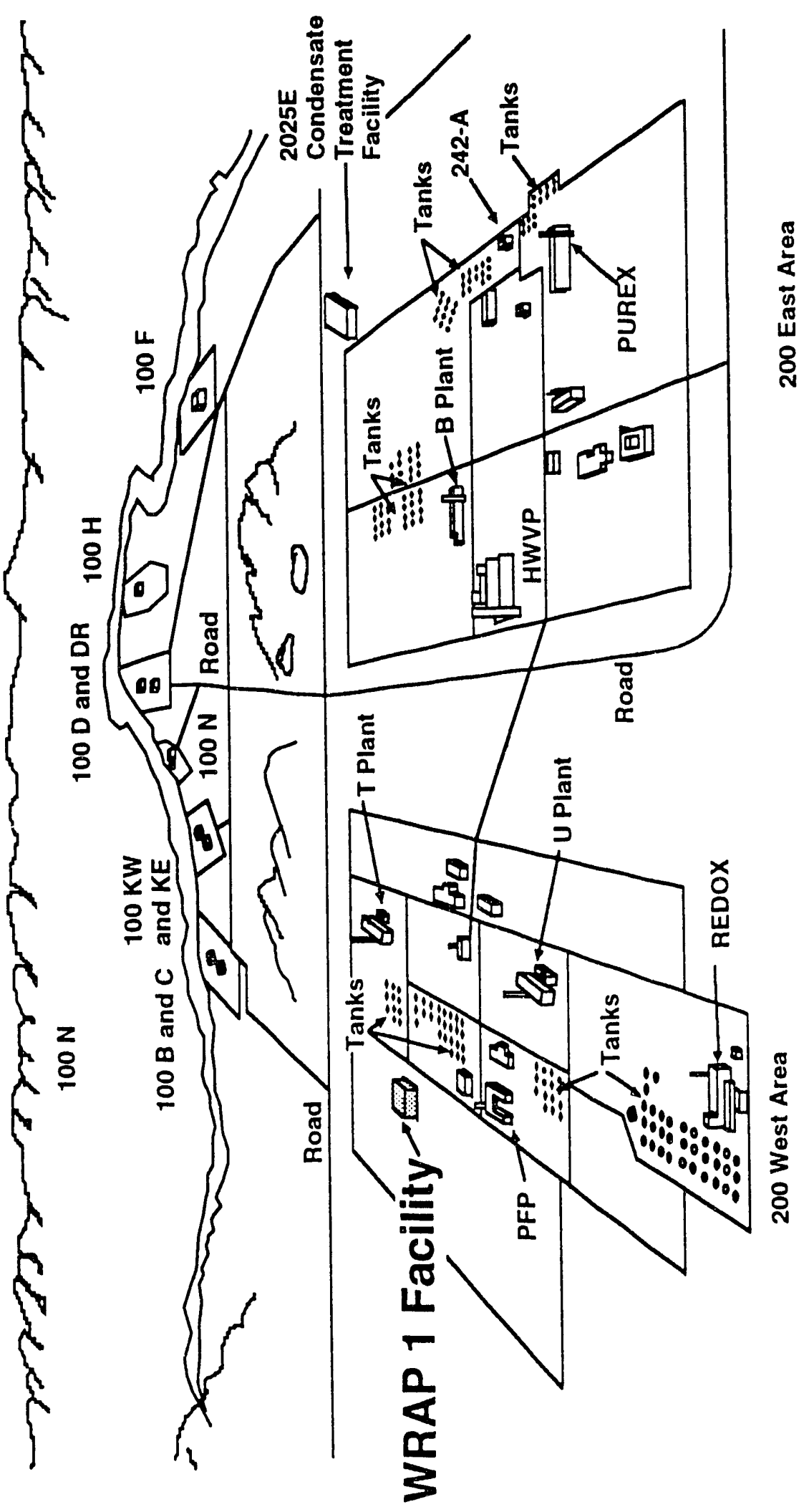

高

م.

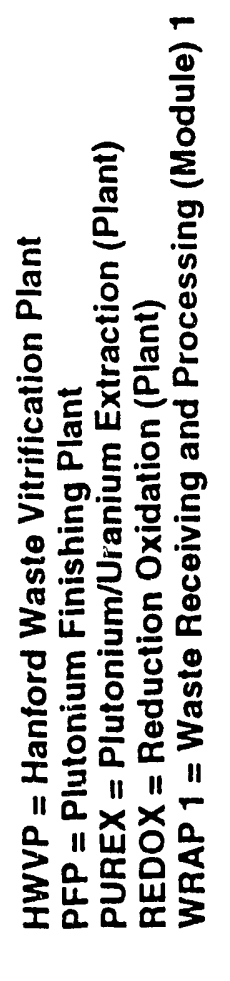


DOE/RL 93-18, Rev. 0

This page intentionally left blank. 


\subsection{OPERATIONS AND PROCESS DESCRIPTIONS}

The following section describes the operations, processing areas, emission sources and emissions control technology of the proposed source.

\subsection{DESCRIPTION OF OPERATIONS}

The solid wastes to be handled in the WRAP 1 facility include low level waste (LLW), transuranic (TRU) waste, and transuranic and low level mixed wastes (LLMW). The WRAP I facility will only accept contact handled (CH) waste containers. Contact handled waste is a waste category whose external surface dose does not exceed $200 \mathrm{mrem} / \mathrm{hr}$. These containers have a surface dose rate of less than $200 \mathrm{mrem} / \mathrm{hr}$.

The primary function of WRAP 1 wi11 be to handle $\mathrm{CH}$ wastes in 55 gal drums. This will include approximately 38,000 retrieved drums containing suspect TRU waste that were placed in storage beginning in 1970 (called retrieved waste), and transuranic drums generated after WRAP 1 start-up in 1997 (called newly generated waste). A secondary function of WRAP 1 will be to examine and assay newly generated $\mathrm{CH}$ waste in boxes up to $2.5 \mathrm{~m}$ (8 ft) 1ong by $1.5 \mathrm{~m}(5 \mathrm{ft})$ wide by $1.5 \mathrm{~m}(5 \mathrm{ft})$ high. This boxed waste will not be opened in WRAP 1. If a box is examined and assayed and found to not meet the acceptance criteria of the permanent disposal facility, the box will be sent to another permitted storage facility in the Hanford Waste Complex to await future processing.

All incoming TRU and retrieved containers will be equipped with particulate filtered vents, and the vapor spaces of the retrieved drums will have been sampled prior to receipt at WRAP 1 . The physical, chemical, and radiological attributes of the newly generated waste is expected to be well known prior to receipt at WRAP 1, while retrieved drums may contain less than fully characterized waste. It is expected that any materials that could emit toxic air emissions will come from the small containers (e.g., aerosol cans, one-liter plastic bottles) packaged inside of the incoming containers. All containers will be maintained in closed condition within the WRAP 1 facility, and only opened inside of gloveboxes (gloveboxes are sealed, ventilated stainless steel enclosures designed to confine radioactive and toxic materials).

The general arrangement floor plan for WRAP 1 is shown on Figure 2-1. The facility is composed of the following areas:

- Shipping and Receiving

- Non-Destructive Examination (NDE) and Non-Destructive Assay (NDA)

- Waste Processing Area

- Ancillary Support areas. 
Figure 2-1. Waste Receiving and Processing Module 1 Facility Floor Plan.

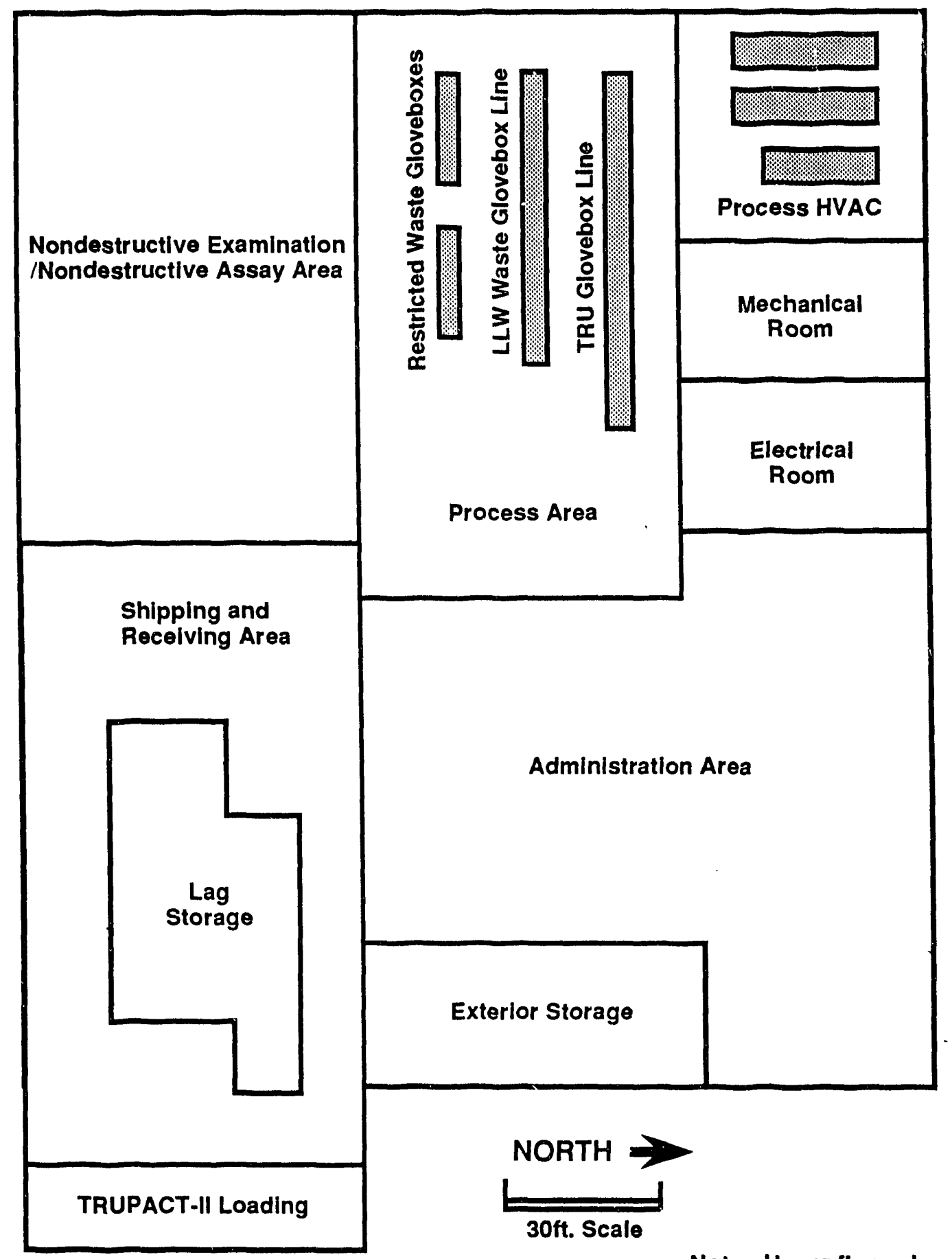

HVAC = Heating, Ventllation, Air Conditioning

Note: Upper floor plan LLW = LoW-level Waste

TRU = Transuranic (waste) containing the control room is not shown 
A schematic showing the flow of materials through these areas is provided on Figure 2-2. The remainder of this section will briefly discuss processing activities taking place in these areas that may result in the release of radioactive or hazardous contaminants.

\subsubsection{Shipping and Receiving}

Waste material will be delivered to, and processed waste containers will be shipped from, basis. In the shipping and receiving area, boxes and drums of waste are unloaded, visually inspected, bar code labeled, radiologically surveyed, and the accompanying shipping manifests examined for completeness and accuracy. All information pertaining to each container will be entered into the plant management system correlated to the bar code identification number.

Following visual inspection, drums and boxes will be transferred to the 1 ag storage area. The shipping and receiving area features an automated stacking, storage, and retrieving system that can accommodate approximately 200 drums packaged four to a pallet. From the lag storage area, incoming drums and boxes are transferred to a weigh station and then on to the NDE/NDA area for further characterization. In the shipping and receiving area, certified TRU waste will be loaded into TRUPACT-2 shipping casks fnr shipment to the Waste Isolation Pilot Plant (WIPP) in New Mexico. Certified LLW will be shipped for disposal on-site while non-certified LLW or LLMW will be moved to permitted storage outside of WRAP 1.

\subsubsection{Non-Destructive Examination/Non-Destructive Assay Systems}

The NDE/NDA area will be used to examine and certify LLW and TRU drums and boxes without opening the drums and boxes. The drums will be transferred to and from the NDE/NDA by means of an Automated Guided Vehicle (AGV) system. Boxes will be transferred to and from the NDE/NDA area by means of a fork lift.

The primary function of the NDE is to examine the physical contents of waste containers (both drums and boxes) entering and leaving the WRAP 1 facility to determine whether there are any non-compliant items or unacceptabie conditions in the containers.

The examination of the physical contents will be accomplished by the use of real time radiography (RTR) system. The RTR system consists of an X-ray imaging system which will be used to identify non-compliant waste items such as particulate material, free or containerized liquids, high efficiency particulate air (HEPA) filters, explosives, compressed gas containers including aerosol cans, and cther suspected hazardous materials. All data from the $x$-ray examination will be input into the plant management system correlated to the bar code identification number for the container. 
DOE/RL 93-18, Rev. 0

Figure 2-2. Waste Receiving and Processing Module 1 Facility Process Flow Diagram.

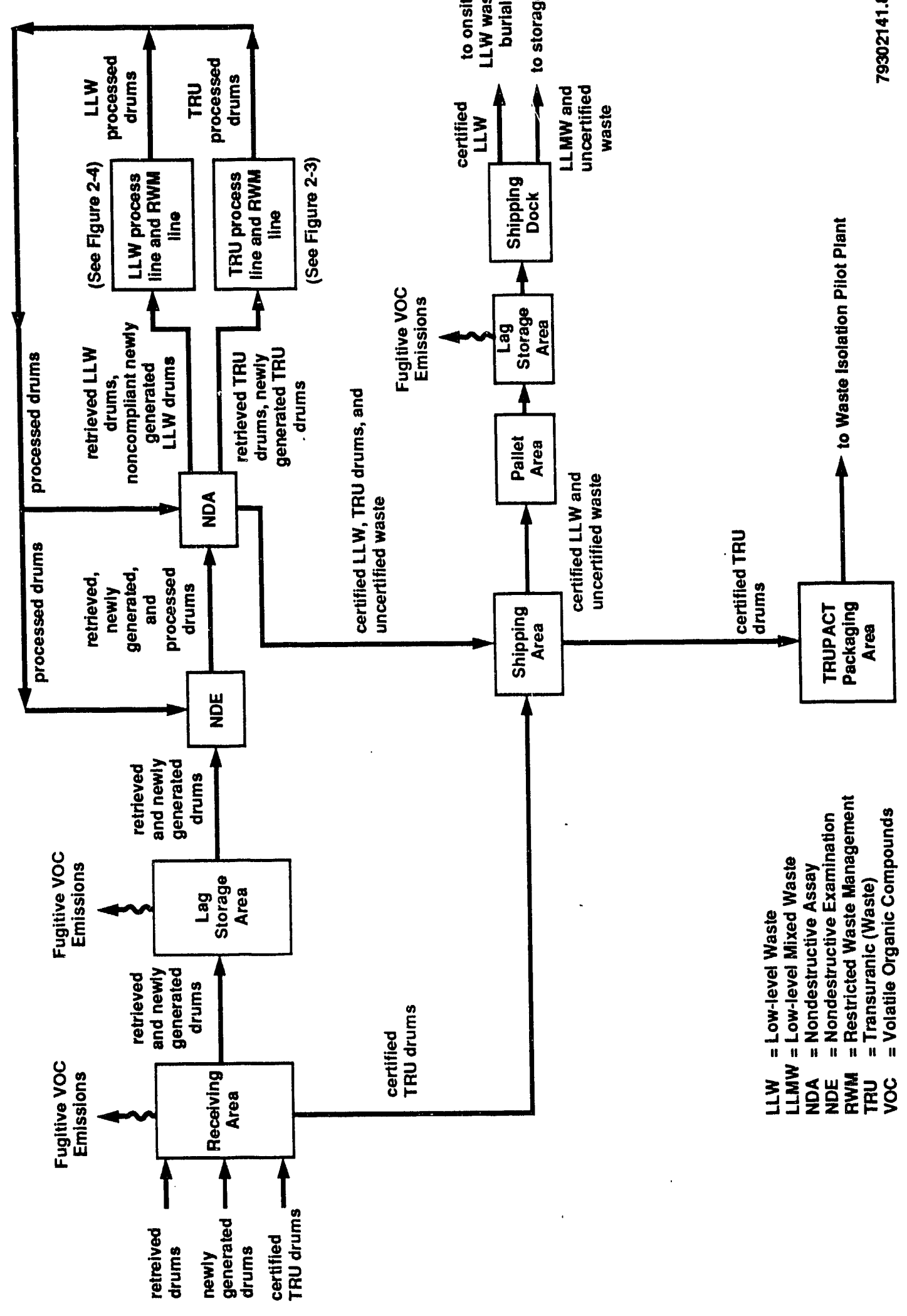


The primary function of the NDA is to determine the activity levels in the waste entering and leaving the WRAP 1 facility. This information will be used to categorize the waste (e.g., TRU, LI.W Class 1, LLW Class 3), provide inventory control information, determine appropriate handling of individual waste containers and determine if the waste meets applicable transportation and disposal criteria. The NDA equipment will include passive-active neutron (PAN) assay systems and gamma energy assay (GEA) systems. Data from each assay of each container will be entered into the plant management system correlated to the bar code identification number of individual containers.

\subsubsection{Processing Area}

Because drums are opened only in gloveboxes, the airborne contaminants produced at WRAP 1 are expected to be generated in these gloveboxes, which are located in the Processing Area.

The processing area consists of four glovebox lines: a TRU Waste Process glovebox, a TRU Restricted Waste Management (RWM) glovebox, a LLW Process glovebox, and a LLW RWM glovebox. Schematics showing the flow of material through the TRU lines and LLW lines are shown on Figure 2-3 and Figure 2-4, respectively. In the process gloveboxes, drums will be opened, the contents sorted, non-compliant items removed and transferred to the RWM gloveboxes, and the remaining compliant wastes sampled and repackaged into new drums.

2.1.3.1 Transuranic Waste Process Line. The TRU Waste Process glovebox consists of stainless steel modular gloveboxes that are bolted together in a linear configuration. The overall TRU Waste Process glovebox is approximately 62 feet long by 4 feet wide by 12 feet high. Windows will be gasketed and bolted to the glovebox wall, and gloveports will be welded to the glovebox wall and accept push-through type gloves. Glovebox ventilation is of the once-though type. Air is drawn from the process room, through a HEPA filter, and into the glovebox. Then the air is exhausted from the glovebox, through another HEPA filter, to the combined glovebox exhaust system.

Waste process operations will be performed inside of the glovebox by using remote controlled manipulators. Drums will be loaded into the glovebox through airlock and sealed type entry systems, non-compliant items will be bar code labelled and transferred to the RWM glovebox using a reusable "bagless" transfer system, and compliant waste will be repackaged into new drums using a double lid transfer system.

2.1.3.2 Transuranic Restricted Waste Management Line. The TRU RWM glovebox is stainless steel and is approximately 20 feet long by 5 feet wide by 12 feet high. Window, gloveport, ventilation, and manipulator features are similar to those described for the TRU Waste Process glovebox. The non-compliant wastes will be received from the TRU Waste Process Line in a reusable double lid transfer container. 
DOE/RL 93-18, Rev. 0

Figure 2-3. Flow Diagram Through Transuranic Gloveboxes.
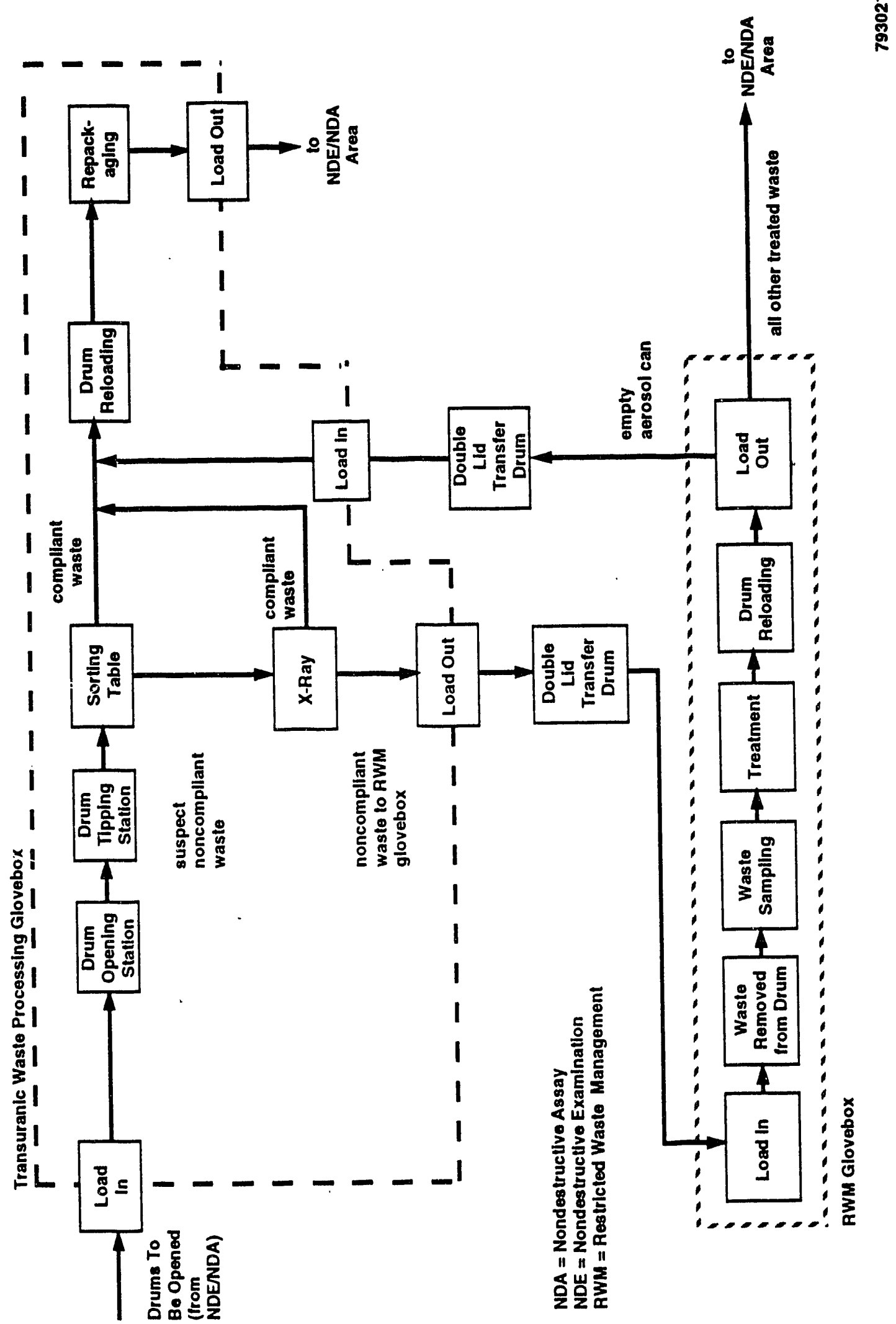
DOE/RL 93-18, Rev. 0

Figure 2-4. Flow Diagram Through Low-Level Waste Gloveboxes.

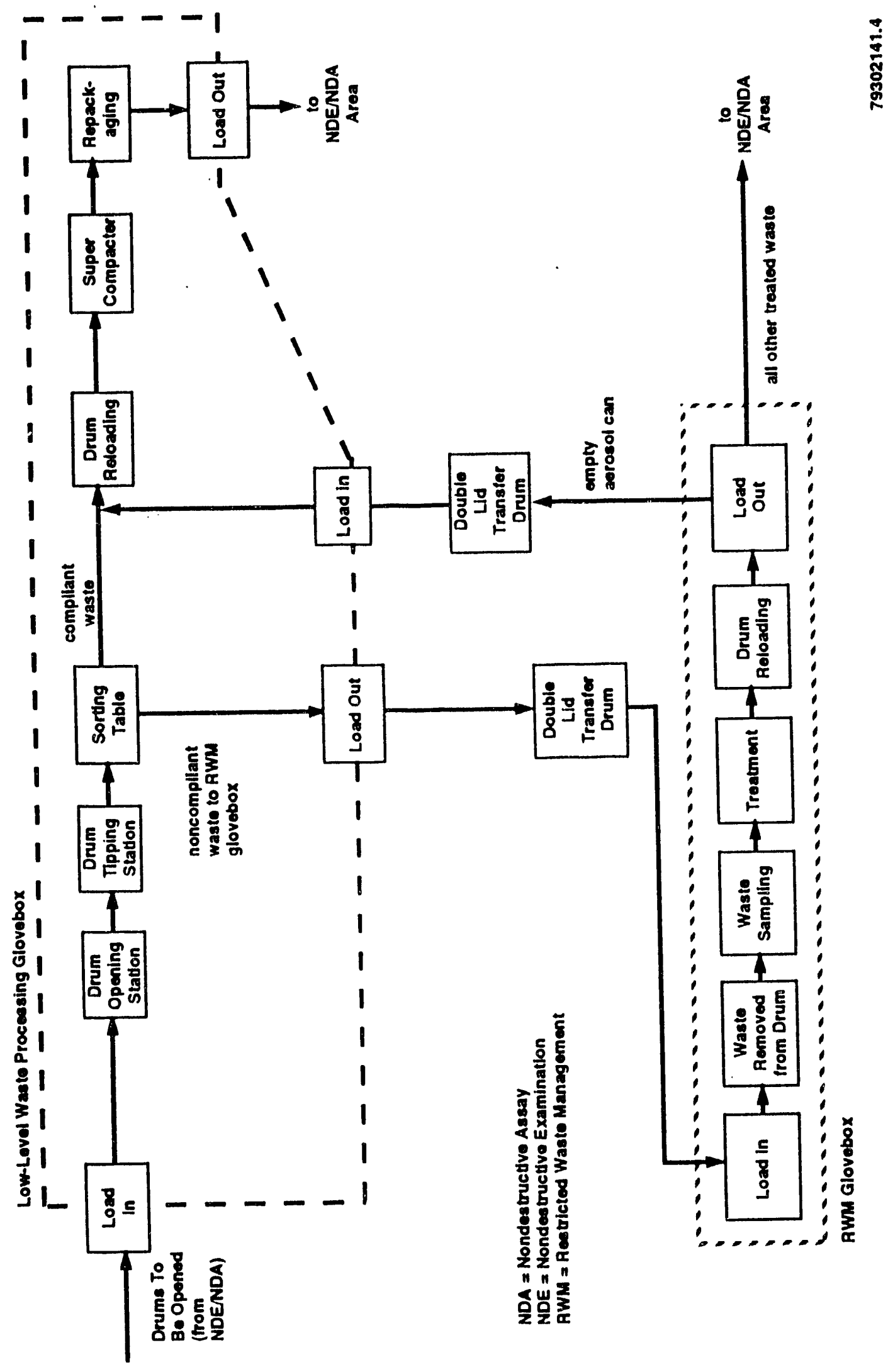


Because the RWM gloveboxes are the only places where individual waste packages will be opened and waste items treated, it is anticipated that the majority of the toxic air emissions will be generated in these enclosures. The treatment operations which will take place in the TRU RWM glovebox on the non-compliant waste following receipt of the sample analysis results will include:

- Aerosol cans will be depressurized and drained. The drained liquids will be retained in containers which will be sent to storage outside the WRAP 1 facility. Vapors from the aerosol cans will be passed through a series of demisters for removal of entrained liquids, and then be vented to the glovebox exhaust

- Spent HEPA filters from incoming drums will be treated with a fixative to immobilize contaminants

- Miscellaneous inorganic liquids will be sampled for characterization, and neutralized, if required, and solidified by using cement additives

- Miscellaneous organic liquids will be sampled for characterization, and repackaged for transfer to storage facilities pending future treatment

- Corrosive materials present in jugs or jars will be neutralized. After neutralization, the materials will be transferred to liquid solidification, particulate immobilization, or loaded out for storage awaiting treatment outside the WRAP 1 facility

- Particulate material not meeting the WIPP criteria will be immobilized with cement or plasticizer additives and sealed in a container.

The empty aerosol cans and other treated packages will be loaded into new drums and routed to the NDA/NDE area.

2.1.3.3 Low-Level Waste Process Line. The LLW Process glovebox consists of stainless steel modular gloveboxes that are boited together in a linear configuration. The overall LLW Process glovebox is approximately 53 feet long by 4 feet wide by 12 feet high. Window, gloveport, ventilation, and manipulator features are similar to those described for the TRU Waste Process glovebox. Drums will be loaded into the glovebox through an airlock entry system, non-compliant items will be bar code labelled and transferred to the RWM glovebox using a reusable "bagless" transfer system, and compliant waste will be repackaged into new drums using a double lid transfer system.

2.1.3.4 Low-Level Waste Restricted Waste Management Process Line. The operations in the LLW RWM Process Line will be identical to the operations in the TRU RWM Line (see Section 2.1.3.2). A description is, therefore, not provided here. 
DOE/RL 93-18, Rev. 0

\subsubsection{Ancillary Support Areas}

The WRAP 1 will contain a number of ancillary support areas. No radioactive waste material will be handled in these support areas, and there is no significant potential for airborne contaminant releases. The process control room will contain a central processor-based plant management system to control and monitor the following:

- Data acquisition

- Data analysis

- Process system surveillance

- Inventory

- Control and surveillance of building utilities.

Other support areas will include the electrical equipment room, mechanical equipment room, HVAC rooms, locker and change rooms, telecommunications room, and administrative areas (i.e., offices, restrooms, lunch room, and conference room).

\subsection{DESCRIPTION OF VENTILATION SYSTEMS}

Ventilation exhaust points at the WRAP 1 facility can be divided into two general categories; the exhaust stack and miscellaneous vents. The exhaust stack will be the emission point for ventilation Zone I (gloveboxes) and ventilation Zone II (rooms in which gloveboxes and Zone I ventilation equipment are located). Toxic air pollutants will be emitted from the exhaust stack. The miscellaneous vents are not anticipated to be a source of toxic air pollutant emissions as discussed in Section 2.2.2.

Areas of WRAP 1 where waste containers are either not handied or are only handled in a closed condition, such as the administrative areas, shipping and receiving areas, and NDE/NDA areas, have essentially no potential for contamination. These areas are considered "uncontrolled" because the air pressure in these areas is not specifically controlled with respect to either atmospheric pressure or other areas of WRAP 1. Exhaust air from these areas is not filtered.

Areas within WRAP 1 where waste containers may be opened are considered potentially contaminated, and these areas will therefore be designated as ventilation zones. Ventilation Zone I includes the areas of highest potential contamination (i.e., gloveboxes and exhaust ducts from gloveboxes). Ventilation Zone II includes areas with lower potential for contamination (i.e., rooms in which Zone I areas are located, other areas with some potential for contamination, and exhaust ducts from Zone II areas). The HVAC system will maintain airflow from noncontaminated areas to areas of progressively higher potential contamination by controlling the air pressure in the ventilation zones. Zone II areas will be maintained at a differential pressure of -0.1 to -0.25 in. water column (wc) with respect to atmospheric pressure, and Zone I areas will be maintained at a differential pressure of -0.7 to -1.0 in. Wc with respect to the rooms in which they are located. 
Also, some areas within a specific ventilation zone will be kept at different pressures with respect to each other to maintain desirable airflow patterns. For example, the air pressure in the Process Roon (room 107) will be maintained at $-0.15 \mathrm{in}$. WC, and the air pressure in the Process HVAC Equipment Room (room 113) will be maintained at $-0.10 \mathrm{in}$. we, both with respect to atmospheric pressure. Although both rooms are ventilation Zone II, this difference in air pressure will maintain the airflow from the Process HVAC Equipment Room to the Process Room.

\subsubsection{Exhaust Stack}

All of the ventilation air that has the potential to contain contaminants will be exhausted through the exhaust stack. This stack will be approximately $14 \mathrm{~m}$ (46 feet) high with a $1 \mathrm{~m}$ (32 in) circular cross section (see

Figure 2-5). The stack will be located approximately $3 \mathrm{~m}$ (10 feet) to the west of the northwest corner of the WRAP 1 facility.

The exhaust stack will be the emission point for ventilation Zone I (gloveboxes) and ventilation Zone II (rooms in which gloveboxes and Zone I ventilation equipment are located). A pressure differential will be maintained in the WRAP 1 facility so that air flows from Zone II to Zone I. A simplified schematic of the Zone I and Zone II ventilation system is provided on Figure 2-6.

Make-up air to Zone II will include approximately $14,505 \mathrm{ft}^{3} / \mathrm{min}$ of supplied air, 1,505 $\mathrm{ft}^{3} / \mathrm{min}$ of in-leakage, and $370 \mathrm{cfm}$ from airlocks. Approximately $930 \mathrm{ft}^{3} / \mathrm{min}$ will flow from Zone II into the Zone I processing gloveboxes due to the differential pressure maintained between Zone I and Zone II. As a result, a total of $16,380 \mathrm{ft}^{3} / \mathrm{min}$ of air will be discharged through the Zone I and Zone II exhaust stack at a temperature of about $90^{\circ} \mathrm{F}$.

2.2.1.1 Zone I Area. The Zone I gloveboxes and the glovebox exhaust system (e.g., including the exhaust ducts, treatment system, and fans) are anticipated to contribute the majority of the toxic air pollutants present in the emissions from the WRAP 1 facility.

The gloveboxes will receive make-up air from the Zone II area in which they are located (i.e., the Process Room). Air will flow from the room into the gloveboxes through push-through filters by virtue of the pressure differential between the gloveboxes and the room. Each of these push-through filters has a rated capacity of $50 \mathrm{ft}^{3} / \mathrm{min}$, and each glovebox will be provided with the appropriate number of push-through filters to prevent the inadvertent migration of contamination from the gloveboxes back into the room through the air inlets. Make-up air to the gloveboxes will include approximately $100 \mathrm{ft}^{3} / \mathrm{min}$ to each of the RWM gloveboxes, $430 \mathrm{ft}^{3} / \mathrm{min}$ to the TRU Waste Processing glovebox, and $300 \mathrm{ft}^{3} / \mathrm{min}$ to the LLW Processing glovebox, for a total of $930 \mathrm{ft}^{3} / \mathrm{min}$ to all of the gloveboxes. 
DOE/RL 93-18, Rev. 0

Figure 2-5. Exhaust Stack.

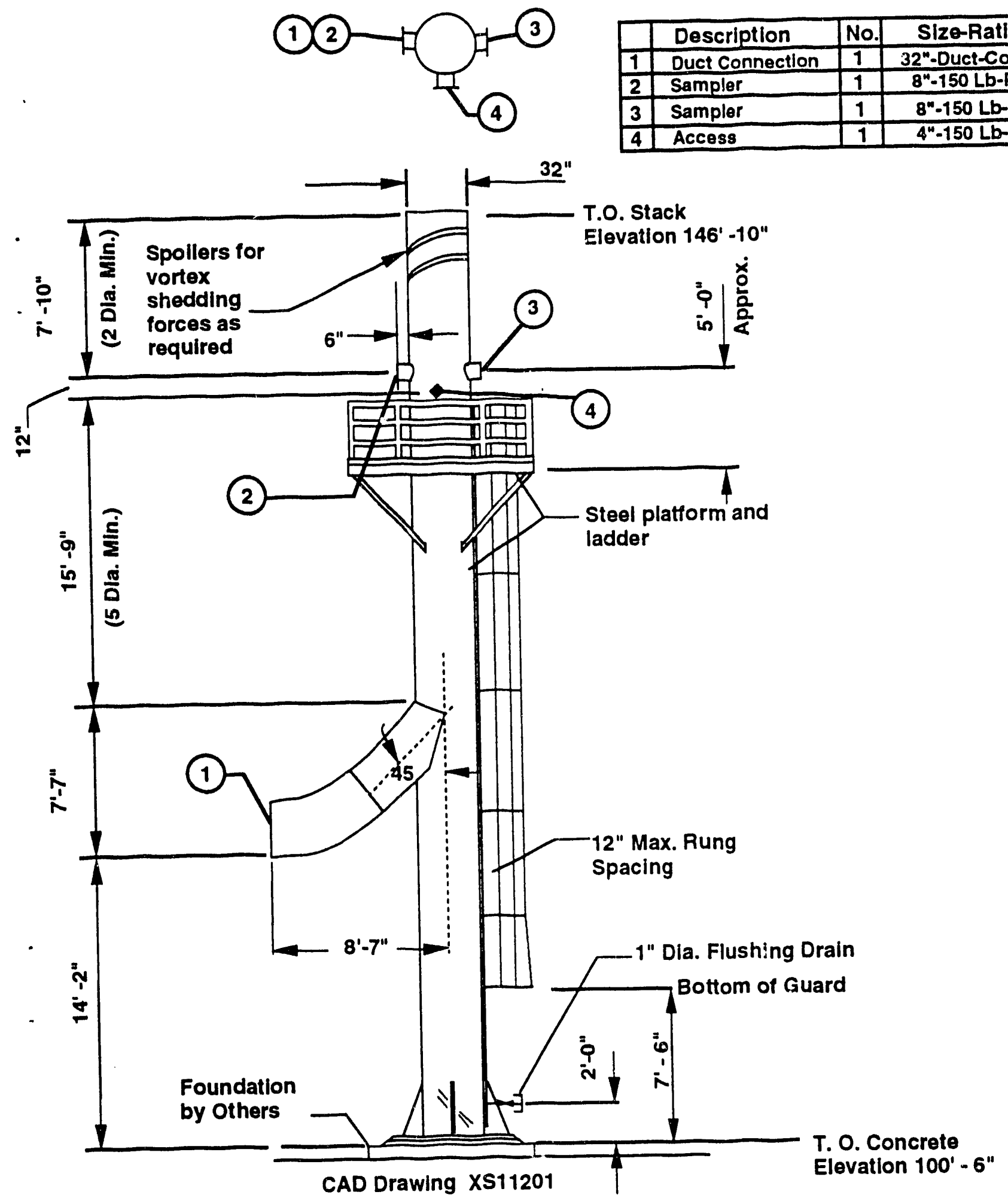

79302141.14 
DOE/RL 93-18, Rev. 0

Figure 2-6. Schematic of Zone I and Zone II Ventilation System.

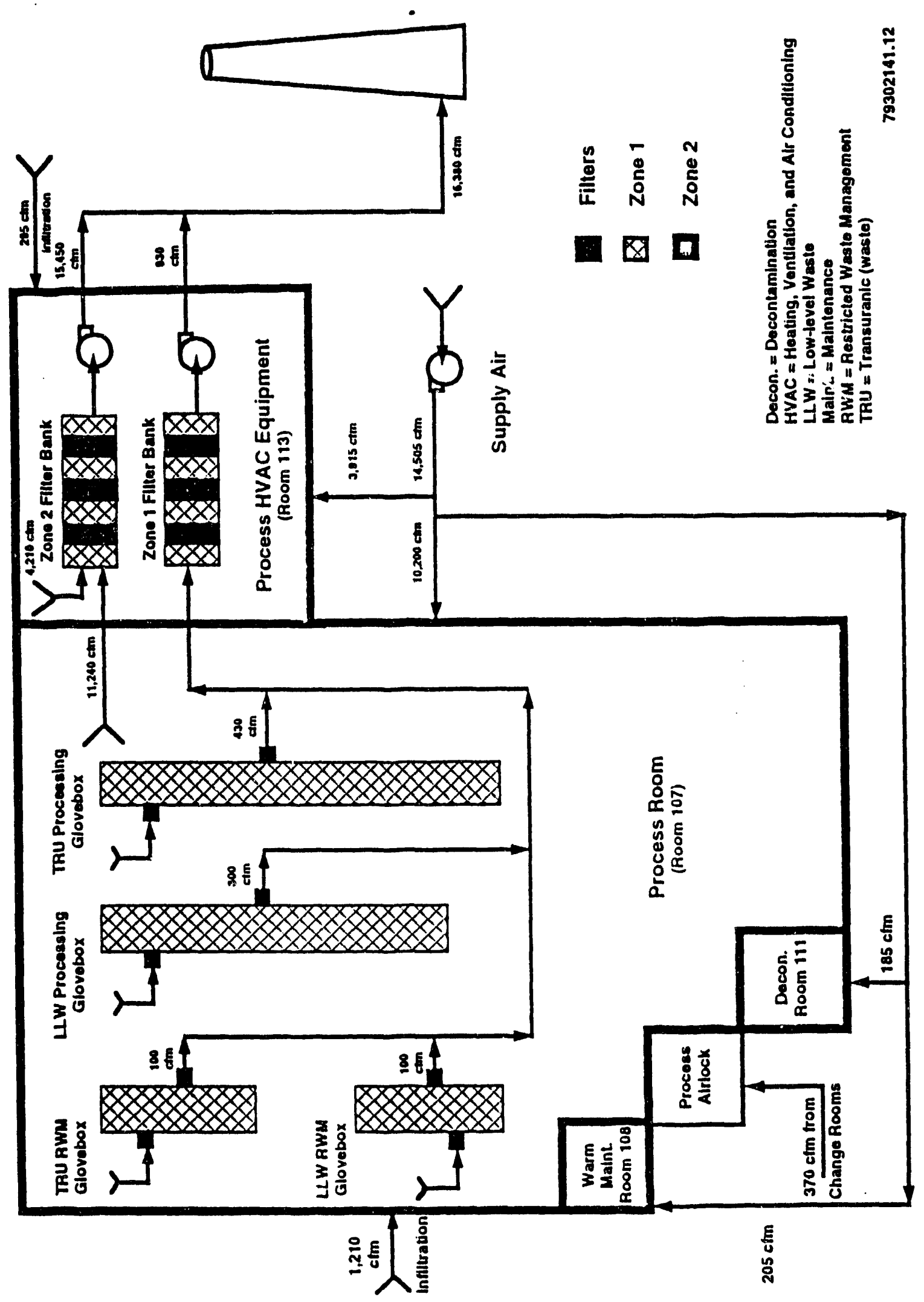


Exhaust air from the gloveboxes will flow through push-through filters to the Zone I exhaust filters, which are separate from the Zone II exhaust filters. Each of these push-through filters has a rated capacity of $50 \mathrm{ft}^{3} / \mathrm{min}$, and each gloveb:x will be provided with the appropriate number of push-through filters to pre'sent the inadvertent migration of contamination from the gloveboxes back into the room through the air outlets. After treatment in the Zone I exhaust filters, the $930 \mathrm{ft}^{3} / \mathrm{min}$ of filtered exhaust air will be combined with the filtered air from the Zone II exhaust system for discharge through the stack.

2.2.1.2 Zone II Areas. Zone II areas include the Process Room (room 107), the Process HVAC Equipment room (room 113), the Decontamination room (room 111), and the Warm Maintenance room (room 108). Ventilation of Zone II areas will be accomplished using use a push-pull, once-through system. Makeup air to Zone II areas will include filtered outside air supplied by fans, planned air in-leakage, and from airlocks. Total make-up air to the Zone II areas from all sources will be approximately $16,380 \mathrm{ft}^{3} / \mathrm{min}$.

A total of approximately $14,505 \mathrm{ft}^{3} /$ min of filtered qutside air will be supplied by fans to the Zone II areas. Of this, $3,915 \mathrm{ft}^{3} / \mathrm{min}$ will be supplied to the Process HVAC Equipment Room, 10,200 $\mathrm{ft}^{3} / \mathrm{min}$ will be supplied to the Process Room, $205 \mathrm{ft}^{3} / \mathrm{min}$ will be supplied to the Warm Maintenance room, and $185 \mathrm{ft}^{3} / \mathrm{min}$ will be supplied to the Decontamination room. Other make-up air will include approximately $1,210 \mathrm{ft}^{3} / \mathrm{min}$ air in-leakage to the process room, $295 \mathrm{ft}^{3} / \mathrm{min}$ a ir in-leakage to the process HVAC room, and $370 \mathrm{ft}^{3} / \mathrm{min}$ from the process airlock that maintains airflow from the change rooms to the Process room.

A total of approximately $15,450 \mathrm{ft}^{3} / \mathrm{min}$ of air will be exhausted by the Zone II exhaust system, and approximately $930 \mathrm{ft}^{3} / \mathrm{min}$ of air will be supplied from the Process Room to the gloveboxes for eventual exhaust by the Zone I exhaust system. The $15,450 \mathrm{ft}^{3} / \mathrm{min}$ of air will be exhausted using a ventilation control and air treatment system which is separate from that used for the Zone I areas. After treatment, the Zone II exhaust will be combined with treated exhaust from the Zone I areas and discharged through the exhaust stack.

\subsubsection{Miscellaneous Vents}

None of the vents described in this section have significant potential for airborne contaminant emissions. Because, as described in Section 2.1.4, they are "ancillary support areas." They are described here only to provide a complete picture of the WRAP 1 facility.

2.2.2.1 Shipping/Receiving and Nondestructive Evaluation/Nondestructive Analysis Areas. The Shipping/Receiving area is located in Room 101, and the NDE/NDA area is located in Room 104. During normal HVAC system operation, air will be recirculated, with only $3,205 \mathrm{ft}^{3} /$ min of air exhausted by leakage through doorways and miscellaneous points. In the economizer mode, $28,830 \mathrm{ft}^{3} / \mathrm{min}$ of air will be exhausted through the wall louver (LV-11-1-1). Emissions from these areas are not anticipated to contain toxic air pollutants. 
Only closed waste containers will be handled in these areas, and the Shipping/Receiving and NDA/NDE areas are separated from the Process Room by a system of airlocks to prevent contaminant migration from the Process Room to the Shipping/Receiving and NDA/NDE area.

2.2.2.2 Locker/Change Rooms. Approximately $1,800 \mathrm{ft}^{3} / \mathrm{min}$ of air from the Locker/Change Rooms will be exhausted through a wall louver (LV-11-302). Emissions from the Locker/Change Rooms are not anticipated to contain toxic air pollutants, since wastes will not be handled in these areas.

2.2.2.3 Administrative Areas. During normal operation, approximately $300 \mathrm{ft}^{3} / \mathrm{min}$ of air will exhaust through wall louver (RV-11-402), from the material preparation room which is part of the administrative and office areas of the WRAP 1 facility. In economizer mode, approximately $9,815 \mathrm{ft}^{3} / \mathrm{min}$ of additional air is exhausted through the wall louver (LV-11-401). Emissions from the administrative areas is not anticipated to contain toxic air pollutants as wastes will not be handled in these areas.

\subsection{OPERATING MODE}

The WRAP 1 facility will process toxic waste up to 24 hours/day (hr/d) (three shifts), 5 days/week (d/wk) (monday through friday), 52 weeks per year (wk/yr). This means the WRAP 1 facility will be operating up to 71.4 percent of the time (based on $24 \mathrm{hr} / \mathrm{d}, 7 \mathrm{~d} / \mathrm{wk}, 52 \mathrm{wk} / \mathrm{yr}$ being equal to 100 percent).

\subsection{SOURCES OF EMISSIONS}

The source term assumes that only $55 \mathrm{gal}$ drums of waste will be handled in such a manner as to potentially release toxic air pollutants, as discussed in Section 2.1. Boxes will not be opened in WRAP 1, and drums will be opened only inside of the gloveboxes. Up to 6,825 drums per year per operating shift, or 20,475 drums per year with 3 shifts operating, will be handled in the WRAP 1 facility (WilC 1992). Of the drums to be processed at WRAP 1 , approximately one-third will be retrieved wastes and approximately two-thirds will be newly generated wastes.

The airborne contaminants produced at WRAP 1 are expected to be generated in the gloveboxes, which are located in the Processing Area. The toxic contaminants are expected to be in the forms of particulates and volatile organic carbons (VOCS). The vast majority of the toxic contaminants expected to be encountered in the waste handled in WRAP 1 are containerized within the drums (e.g., one liter jugs of liquids, partially full aerosol cans), and these containers will be opened only in the RWM gloveboxes. Therefore, it is expected that essentially all of the toxic air emissions from WRAP 1 will be generated in the RWM gloveboxes, which are part of Ventilation Zone $I$.

An estimate of the types and quantities of hazardous materials which will be handled in WRAP 1, from which toxic air pollutants could be generated, is summarized in Table 2-1. Air emissions could result from the suspension or volatilization of all or portions of these materials during the waste processing steps described in Section 2.1.3. 
Table 2-1. Estimated Toxic Substance Contents of Drums to be Processed i:. Waste Receiving and Processing Module 1 Facility.

\begin{tabular}{|lcc|}
\hline & $\begin{array}{c}\text { Average } \\
\text { Curies/ } \\
\text { Drum } \\
\text { Radioisotopes }\end{array}$ & $\begin{array}{c}\text { Process } \\
\text { Rate } \\
\text { (Ci/drum) }\end{array}$ \\
\hline PARTICULATE RADIONUCLIDES
\end{tabular}

Notes:

Based on processing 20,475 drums per year. 


\subsection{EMISSIONS CONTROL TECHNOLOGY}

Particulate toxic air pollutants will be controlled through the use of High Efficiency Particulate Air (HEPA) filters. HEPA filters commonly are used for the removal of submicron particles in the nuclear industry. HEPAs are disposable, extended-medium, dry filters with a rigid casing enclosing the full depth of the pleats. They have a particle removal efficiency range of 99.95 percent to 99.99 percent for 0.3 micron thermally-generated, monodispersed dioctylphthalate (DOP) particles, and a maximum pressure drop of 1 inch of water column when clean and operated at rated airflow capacity. The core of a HEPA filter is generally made by pleating a continuous web of fiberglass paper back and forth over corrugated separators that add strength to the core and provide air passages between the pleats. The core is then sealed in a wood or metal casing (frame). The filter paper itself is composed of very fine (submicron) glass fibers in a matrix of larger ( 1 to 4 micron) fibers and held together with an organic binder.

The WRAP 1 waste processing operations are provided with ventilation Zones I and II that have a negative pressure gradient from Zone II to Zone I to provide maximum confinement of air pollutant contamination. Zones I and II will use a once-through, push-pull type ventilation system (see description in Section 2.2.1.1).

Zone I ventilation areas in which the toxic materials are processed, obtain inlet air from the Zone II room in which they are located. The glovebox structures and penetrations are designed to confine the contaminants within Zone I. Zone I and Zone II exhausts are each ducted to their own HEPA filtration banks, each bank consisting of two stages of HEPA filters, before being combined and subsequently discharged to the atmosphere. Zone I and Zone II each have two banks of HEPA filters, with one serving as backup to the other. During routine maintenance activities (e.g., filter change-out) or in the event of a failure of an equipment component, the exhaust flow is diverted to the backup filter bank.

The measures, as described above, allow for high-efficiency removal of particulate toxic air pollutants which provides for system redundancy in the event of a possible failure of one of the emission control units. The expected emissions are compatible with the filtration system. In addition, the WRAP 1 gloveboxes are equipped with non-testable HEPA filters on both the inlet and outlet flows to minimize the contamination of the exhaust ducts and final filter banks (NOTE: Because these filters are not testable, no credit is taken for them in Section 3.0, "Toxic Air Pollutant Emissions Estimations.")

The uncontrolled VOC emission rates are low enough that the airborne concentrations at the Hanford Site boundary are much lower than the Acceptable Source Impact Level (ASIL) concentration limits. Emissions from the WRAP 1 facility are sufficiently low to protect human health and safety from potential carcinogenic and/or other toxic effects. Therefore, no controls satisfy Best Available Control Technology for Toxics (TBACT) (WHC 1993). 


\subsection{TOXIC AIR POLLUTANT EMISSION ESTIMATIONS}

By the very nature of the WRAP 1 facility, detailed data on the toxic air pollutants present in the matariais to be processed in WRAP 1 are not available to develop a precise suurce terin. Therefore, several key assumptions have been made in estimating the uncontrolled toxic air pollutant release rates. These assumptions are presented in this section. The resulting estimated uriscr:rolled release rates are presented for all Zone I areas in Table 3-1.

\subsection{ESTIMATED TOXIC SUBSTANCE CONTENT OF THE WASTES}

The amounts and types of toxic substances anticipated to be present in the waste drum processed it WRAP 1 are summarized in Table 2-1. Uncontrolled toxic air polluicini re? ease rates from the WRAP 1 facility have been estimated using a source term developend from histarical data on the processes which generated the wastas and know?edgo of the hazardous constituents generally contained in the items disposed of from the waste-generating processes (WHC 1992.). Several potential sources of toxic air pollutants may be present. These include leaded materials; aerosol cans; scintillation vials; rags and adsorbents used to cleanup spills; fluorescent light tubes; and small sealed containers and labpacks of solvents, oils, paints, paint thinners, and analytical reagents. Assumptions used to develop these estimates are briefly summarized below (WHC 1992).

\subsubsection{Leaded Materials}

Lead is used extensively for radioactive shielding in process buildings at the Hanford Site. The lead is usually contained in leaded gloves, lead bricks, lead wool, and lead pellets, and as such is not highly mobile. The source term assumes that approxinately 1 percent of all of the drums to be processed in WRAP 1 will contain up to $13.5 \mathrm{~kg}(301 \mathrm{~b})$ uf lead in these forms.

\subsubsection{Fluorescent Light Tubes}

Barium, cadmilim, and mercury are present in wastes containing either intact or crushed fluorescent light tubes. The source term assumes that approximately 1 percent of all of the waste drums to be processed by WRAP 1 will contain up to $0.05 \mathrm{~kg}(0.1 \mathrm{lb})$ each of barium, cadmium, and mercury.

\subsubsection{Aerosol Cans}

Aerosol cans containing spray paints, degreasing sulvents and cleaning agents, paint strippers, and adhesives are known to be present in the wastes to be processed in WRAP 1 (WHC 1992). Based on current Material Safety Data Sheet (MSDS) information, it is anticipated that these products will contain a wide variety of organic and inorganic compounds. Additionally, aerosol propellants will be present, including propane and isobutane in more recent 


\section{Table 3-1. Estimated Emissions from Zone I and Restricted} Waste Management Gloveboxes.

\begin{tabular}{|c|c|c|c|c|c|c|c|}
\hline \multirow[b]{2}{*}{ Species } & \multirow[b]{2}{*}{$\begin{array}{r}\text { Annual } \\
\text { Material } \\
\text { Processed } \\
\text { in } 1 \mathrm{~b} / \mathrm{yr} \\
\end{array}$} & \multicolumn{2}{|l|}{$\begin{array}{l}\text { Toual Zonet } \\
\text { Emissions }\end{array}$} & \multicolumn{2}{|c|}{$\begin{array}{l}\text { Emissions Irom } \\
\text { RWM Gloveboxes }(1)\end{array}$} & \multirow[b]{2}{*}{$\begin{array}{l}\text { Chapter } \\
173-460 \text { WAC } \\
\text { Small Quantity } \\
\text { Rate } \\
\text { Limit in } \\
\text { lb/yr (4) }\end{array}$} & \multirow[b]{2}{*}{ Comrone } \\
\hline & & $\begin{array}{l}\text { Annual } \\
\text { Average } \\
\text { Emission } \\
\text { Rate in } \\
\text { Ib/yr II }\end{array}$ & $\begin{array}{r}\text { Peak } \\
\text { Duily } \\
\text { Rate } \\
\text { in } \\
\text { day (2) } \\
\end{array}$ & $\begin{array}{l}\text { Annual } \\
\text { Average } \\
\text { Emission } \\
\text { Rate in } \\
\text { lb/yr } \\
\end{array}$ & $\begin{array}{l}\text { Peak } \\
\text { Daily } \\
\text { Average } \\
\text { Rate in } \\
\text { Ib/dy(2) } \\
\end{array}$ & & \\
\hline \multicolumn{8}{|l|}{ Carinorenic VOCs (CVOCs) } \\
\hline dichloroethane & 1.620 & 367.9 & 10.1 & 331.11 & 9.07 & 500 & \\
\hline carbon tetrachloride & 690 & 39.8 & $1: 1$ & 35.86 & 0.98 & 10 & \\
\hline formaldehyde & 30 & $\underline{0.2}$ & $\underline{0.0}$ & $\underline{0.18}$ & $\underline{0.00}$ & 20 & \\
\hline Subtotal CVOCs & 2.340 .0 & 407.9 & 11.2 & 367.1 & 10.1 & & \\
\hline \multicolumn{8}{|c|}{ Non-Careinogenic VOCs (NCVOCs) } \\
\hline trichlorocthane & 1.350 & 87.6 & 2.10 & 78.34 & 2.16 & 22.750 & \\
\hline xylene & 930 & 4.2 & 0.12 & 3.30 & 0.10 & 43.748 & \\
\hline toluene & 840 & 12.0 & 0.33 & 10.79 & 0.30 & 43,748 & \\
\hline 2-butanone & 720 & 38.3 & 1.05 & 34.48 & 0.94 & 43,748 & \\
\hline 4-rnechyl 2-pentanone & 150 & 0.5 & 0.01 & 0.44 & 0.01 & 43.748 & \\
\hline acetone & 690 & 81.5 & 2.23 & 73.33 & 2.01 & $\$ 3.748$ & \\
\hline 2-propanol 1-methoxy acetate & 120 & 3.7 & 0.10 & 3.29 & 0.09 & NA & \\
\hline propane & 660 & 660.0 & 13.08 & 594.00 & 16.27 & NA & Propellant \\
\hline isobutane & 600 & 600.0 & 16.4. & 540.00 & 14.79 & NA & Propellant \\
\hline hexane & 930 & 76.6 & 2.10 & 58.97 & 1.39 & 43.748 & \\
\hline heptane & 750 & 17.5 & 0.48 & 15.77 & 0.43 & 43.748 & \\
\hline tributyl phosphate & 130 & 1.6 & 0.04 & 1.47 & 0.04 & 175 & \\
\hline trimethyl benzene & 90 & 0.2 & 0.00 & 0.16 & 0.00 & 43.748 & \\
\hline echyl benzene & 130 & 03 & 0.02 & 0.74 & 0.02 & 43.748 & \\
\hline 1-mechoxy 2-propanol & 180 & 1.4 & 0.04 & 1.26 & 0.03 & 43.748 & \\
\hline 5-methyl 2-hexanone & 90 & 0.2 & 0.01 & 0.21 & 0.01 & $N A$ & \\
\hline mechanol & 1.170 & 72.1 & 1.98 & 64.91 & 1.78 & 43.748 & \\
\hline n-butyl alcohol & 60 & 0.2 & 0.01 & 0.13 & 0.00 & 43.748 & \\
\hline isopropyl alcohol & 390 & 8.4 & 0.23 & 7.52 & 0.21 & 43.748 & \\
\hline ethyl alcohol & 420 & 11.7 & 0.32 & 10.55 & 0.29 & 43,748 & \\
\hline ammonium hydroxide & 60 & 23.4 & 0.64 & 21.02 & 0.58 & 43.748 & \\
\hline $\begin{array}{l}\text { ethyleno alveol monoburyl ether } \\
\text { Subtotal NCVOCs }\end{array}$ & $10.590 \frac{30}{0}$ & $1.70 \underline{0.2 .1}$ & $\frac{0.00}{46.6}$ & $1.5 \frac{0.16}{31.9}$ & $\frac{0.00}{+2.0}$ & 43,748 & \\
\hline \multicolumn{8}{|l|}{ Chlorinated Fluorocarbons (CFCs) } \\
\hline dichlorodifluoro methane & 1.090 & 1080.0 & 29.59 & 972.00 & 26.63 & 43.748 & Propellant \\
\hline erichlorotrifluoro ethane & 15 & 2.7 & 0.07 & $2 .+4$ & 0.07 & 43.748 & \\
\hline trichlorofluoro methane & 60 & 26.5 & 0.73 & 23.36 & 0.65 & 43,748 & \\
\hline chlorodlnuoro methane & $\underline{360}$ & $\underline{360.0}$ & 9.36 & 324.00 & 3.38 & 43,748 & Propellant \\
\hline Subtotal CFCs & 1.515 .0 & 1.4692 & 40.3 & 1.322 .3 & 36.2 & & \\
\hline Toual Volatiles & 14,445 & 3.579 & 98 & 3.221 & 38 & & \\
\hline \multicolumn{8}{|l|}{ Particulare Carcinogens } \\
\hline polychlorinated biphenyls & 600 & 0.6 & 0.02 & 0.54 & 0.01 & NA & \\
\hline cadmium & 21 & 0.021 & 0.00 & 0.02 & 0.00 & None & \\
\hline \multicolumn{8}{|l|}{ Pariculate Non-carcinogens } \\
\hline barium & 21 & 0.021 & 0.00 & 0.02 & 0.00 & 175 & \\
\hline mercury & 21 & 0.021 & 0.00 & 0.02 & 0.00 & 175 & \\
\hline lead (3) & 6.000 & 6 & 0.16 & 5.10 & 0.15 & 175 & \\
\hline Tocal Particulates & 6.663 & 6.7 & 0.18 & 6.0 & 0.16 & & \\
\hline
\end{tabular}

(1) Assumes that 909 of lotal Zone I emissions sre contributed by RWM gloveboxes.

(2) Assumes 10x peak daily factor.

(3) Chapier $173-160$ IVAC smail quantity limits based upon lead acetare or lead shromate.

(4) -None* means compound is requiated by Chapter 173-160 iVAC. bute no small quantiry generator limits have been escablished.

"NA" means compound is nor regulated under Chaprer $173-560 \mathrm{w}, 4 \mathrm{C}$.

T3-Irev 
waste materials, and chlorinated fluorocarbons (CFCs) in waste materials generated prior to 1978. Propane cylinders were also used in various Hanford processing activities and may also be present in the wastes processed in WRAP 1.

The source term assumes that each of the retrieved waste drums will contain an average of one aerosol can. Of these, half of the aerosol cans are projected to contain CFC propellants, with a mixture of 75 percent dichloro difluoro methane (Fluorocarbon 12) and 25 percent chloro difluoro methane (Fluorocarbon 22). The remaining aerosol cans are projected to contain isobutane and propane propellants in a 50/50 mixture. In all cases, each can will contain an average of $0.5 \mathrm{~kg}(1 \mathrm{lb})$ net contents, with propellant making up 30 percent of the net contents. The aerosol cans are assumed to be equaliy divided between spray paints, glass cleaners, and miscellaneous products. The miscellaneous products are assumed to be equally divided between Fabrifilm, strippable coatings, teflon ${ }^{2}$, degreaser, paint stripper, flux remover, spray adhesive, freon ${ }^{2}$ solvent, and contact cleaner.

Only retrieved waste drums from the Plutonium Finishing Plant, constituting approximately 55 percent of the stored suspect TRII waste, will contain propane cylinders. It has been assumed that the cylinders will occur in approximately 1 percent of the Plutonium Finishing Plant waste drums.

\subsubsection{Miscellaneous Liquids, Lab Packs, and Scintillation Vials}

Containerized liquids containing organic wastes, including hydraulic fluids (some contaminated with polychlorinated biphenyls), oils, solvents, cleaners, paints, paint thinners and removers, and adhesives are known to be present in the wastes to be processed in WRAP 1. Lab packs with containers of miscellaneous laboratory chemicals, ranging up to $3.8 \mathrm{~L}$ (1 gal) in size will al so be processed. Wastes will also contain discarded scintillation vials, packaged up to 2,000 per drum and containing residual amounts of spent scintillation fluid. Rags and adsorbents used to cleanup spills and saturated with the above materials are also known to be present in the waste.

The source term assumes that, of the retrieved waste, approximately 1,000 drums will contain these materials. It has been assumed that these drums will occur at a rate of one in every 40 drums processed, or at a frequency of approximately 200 drums per year. These drums will be equally distributed between miscellaneous containerized liquids, lab packs, and scintillation vials. Miscellaneous containerized liquids are assumed to be packaged at an average of $22.5 \mathrm{~kg}(50 \mathrm{lb})$ per drum, and distributed over six yeneral classifications of materials, with up to 25 percent of the oils containing polychlorinated biphenyls. It is assumed that the drums containing scintillation vials will contain approximately $4 \mathrm{~kg}(9 \mathrm{lb})$ per drum of

${ }^{1}$ Fabrifilm is a Trademark of Turco Products, Westminster, California.

${ }^{2}$ Teflon and Freon are Trademarks of E.I. DuPont De NeMours \& Co., Wilmington, Delaware. 
scintillation fluid. It has been further assumed that the lab packs contain an average of $22.5 \mathrm{~kg}(50 \mathrm{lb})$ per drum of common discarded analytical reagents packaged in small (less than 1 L) containers.

\subsection{ANTICIPATED TOXIC AIR POLLUTANT EMISSIONS}

Waste drums will be only opened in the gloveboxes; it is therefore expected that the ventilation Zone I areas will be the major source of toxic air pollutants. The most invasive processes, including waste treatment, will occur in the two RWM gloveboxes. Therefore, it is anticipated that the majority of the toxic air pollutants released into the Zone I ventilation system will be emitted from the RWM gloveboxes. Materials will be transferred into and out of the gloveboxes in the processing rooms. Additionally, minor ventilation flow reversals may also occur. In both of these instances, minor amounts of toxic air pollutants may be released into the Process Room, and from there into the Zone II ventilation system.

For purposes of this analysis, it is assumed that 90 percent of the total amount of toxic air pollutants emitted from Zone I will originate from the RWM gloveboxes, where the aerosol cans will be opened and drained. Furthermore, it was assumed that no VOC emissions will occur in Zone II because the drums will be stored there and not opened, for only a short time.

\subsubsection{Annual Average Emission Rate Assumptions}

Appendix A describes the methods that were used to estimate the annualaverage emission rates. It was assumed that all of the toxic air pollutants with a reported vapor pressure greater than $760 \mathrm{~mm} \mathrm{Hg}$ at room temperature are aerosol can propellants, which would be emitted in their entirety. For example, $297 \mathrm{~kg}(660 \mathrm{lb}$ ) per year of propane (with a vapor pressure of $6,500 \mathrm{~mm} \mathrm{Hg}$ ) are anticipated to be present in the wastes processed by WRAP 1 ; therefore, $297 \mathrm{~kg}$ (660 1b) per year of propane are assumed to be emitted.

For volatile species with reported vapor pressures less than $760 \mathrm{~mm} \mathrm{Hg}$ at room temperature, it was assumed that they are present only in aerosol cans that will be punctured and drained. Evaporative losses will occur after the contents of the cans are drained into pans for transfer to a sealed disposal container. The emission rates were calculated assuming that volatile liquids would be present with a surface area approximately $0.5 \mathrm{~m}(1.6 \mathrm{ft}$ ) in diameter, exposed to the glovebox air for a period of 24 hours per day. Emission rates were then predicted using empirical correlations for gas-phase controlled convective mass transfer, as described in Appendix A.

For particulate species, it was assumed that 0.1 percent by weight of the materials contained in the drums would be emitted. This emission factor is the same one used to estimate radionuclide emissions from solids ( 40 CFR Part 61, Appendix D, Table 1). 


\subsubsection{Peak Daily Emission Rate Assumptions}

It was assumed that the peak daily emission rate for all toxic air pollutants would be ten times the average daily emission rate. This "peaking factor" accounts for the potential that some drums could contain more volatile organic compounds than the average. The daily average emission rates were assumed to be equal to the annual emission rates divided by 365 days per year.

\subsubsection{Uncontrolled Releases from Zone 1 Gloveboxes}

The estimated uncontrolled emissions concentrations and total release rates from the Zone 1 gloveboxes are provided in Table 3-1. Both annual average and peak daily average concentrations and rates are provided. It was assumed that 90 percent of the total Zone I emissions would occur at the RWM gloveboxes. A total of $1,630 \mathrm{~kg}(3,579 \mathrm{lb})$ per year of VOCs and $2.7 \mathrm{~kg}$ (6.0 1b) per year of particulate solids are expected to be emitted from the combined gloveboxes. Of the $1,630 \mathrm{~kg}(3,579 \mathrm{lb})$ per year of VOCs emitted, about $1,250 \mathrm{~kg}(2,760 \mathrm{lb})$ per year are contributed by propellants from the aerosol cans. Table 3-1 compares the estimated emission rates for each compound with the Smal1 quantity Emission Rate limits from WAC 173-460. The emission rates for the non-carcinogenic VOCs and the chlorofluorocarbons are far below the small quantity limits. The estimated emission rates of the carcinogenic VOCs exceed the small quantity limits. Therefore, dispersion modelling was performed to confirm compliance with the ASILs.

\subsubsection{Fugitive Emissions}

The release of small amounts of toxic air pollutants from drums currently in storage at Hanford Site facilities has been documented. Samples of the airspace around 10 drums of waste generated between 1986 and 1991 were collected and analyzed in 1991 (SAIC 1991a). These drums were known to contain volatile or semivolatile compounds, including carbon tetrachloride, mercury, and tributyl phosphate. Concentrations of mercury vapor in the headspace of these drums have been estimated to be up to $0.009 \mathrm{mg} / \mathrm{m}^{3}$. Total concentrations of carbon tetrachloride in the drum headspace were estimated to be as high as approximately 6,000 ppm. Acetone, methyl ethyl ketone, methy 1 isobutyl ketone (MIBK), hexane, benzene, xylene, and toluene were also tentatively identified as present in the drum vapor space.

Samples of the ambient air inside one of the buildings currently used to store wastes destined for WRAP 1 have also been analyzed for toxic air pollutants (SAIC 1991). Very low concentrations of benzene (ranging up to $1.9 \mathrm{ppm}$ ); carbon tetrachloride (up to $0.15 \mathrm{ppm}$ ); chloroform (up to $0.23 \mathrm{ppm}$ ); total hydrocarbons (up to $0.132 \mathrm{ppm}$ ); methylene chloride (up to $1.6 \mathrm{ppm}$ ); toluene (up to $1 \mathrm{ppm}$ ); and trichloroethylene (up to $0.11 \mathrm{ppm}$ ) were detected in the ambient air samples. Acetone, MIBK, and xylenes were not detected above the method detection limits of the analysis.

Table 3-2 lists the estimated worst-case emission rates that would be expected to occur during storage of an assumed 260 closed drums at a time at the indoor drum receiving facility at WRAP 1. The emission rates were estimated by assuming that all of the drums would emit at the average rate 
that was measured during the he ace testing at the TRUSAF facility (SAIC 1991a). The estimated emission rate for carbon tetrachloride is about $5.2 \mathrm{~kg}(11.6 \mathrm{lb})$ per year, assuming 100 drums are constantly stored indoors. The "miscellaneous hydrocarbons" listed in Table 3-2 include acetone, MIBK, benzene, and xylenes. Mercury vapor is expected to be emitted at the insignificant rate of about 0.000001 pound per year.

Based upon these estimates, wastes that are merely stored and examined by NDE/NDA are not expected to significantly contribute to the toxic air pollutant emissions from the WRAP 1 facility. Therefore, no significant amounts of toxic air pollutants will be emitted from the miscellaneous facility vents described in Section 2.2.2.

Table 3-2. Estimated Volatile Organic Compound Emissions from Indoor Drum Storage (Based on Indoor Storage of 260 Closed Drums).

\begin{tabular}{|l|c|c|}
\hline \multicolumn{1}{|c|}{ Compound } & $\begin{array}{c}\text { Average emissions per } \\
\text { drum (lb/year) }\end{array}$ & $\begin{array}{c}\text { Estimated annual } \\
\text { emissions (1b/year) }\end{array}$ \\
\hline Carbon Tetrachloride & $3.2 \mathrm{E}-04$ & 30.15 \\
\hline $\begin{array}{l}\text { Miscellaneous } \\
\text { hydrocarbons }\end{array}$ & $9.9 \mathrm{E}-06$ & 0.94 \\
\hline Mercury vapor & $3.3 \mathrm{E}-11$ & 0.00 \\
\hline
\end{tabular}

\subsection{ABATED PARTICULATE TOXIC AIR POLLUTANT EMISSIONS}

The estimated particulate toxic air pollutant emissions are listed in Table 3-1. Both the annual average and peak daily average concentrations and rates are provided. The concentrations and rates listed do not reflect the abated emissions as a result of the emission control system. The emission control system will be capable of containing micrometer- and submicrometersized particles. The control system contains two HEPA filters in series, which will make the total efficiency 99.99995 (Carter 1993).

The polychlorinated biphenyl particulates are not regulated under the TAPs regulations. The particulates barium, mercury, and lead, have estimated emission rates which fall below the small quantity rates. For the particulate cadmium, no small quantity rate limit has been established under the TAPs regulation. Therefore, the concentration of cadmium in the facility effluent was compared to the ASIL. The estimated abated emission rate of cadmium $\left(2.0 \mathrm{E}-08 \mu \mathrm{g} / \mathrm{m}^{3}\right) \mathrm{fell}$ well below the ASIL listed in the regulation $\left(5.6 \mathrm{E}-04 \mu \mathrm{g} / \mathrm{m}^{3}\right)$. 
DOE/RL 93-18, Rev. 0

\subsection{AIR QUALITY IMPACT ANALYSIS}

Maximum offsite concentrations resulting from emissions of toxic substances from the WRAP 1 facility were modeled following U.S. Environmental Protection Agency (EPA) guidance (EPA 1986a) using Hanford Site meteorology and terrain data. The emissions, modeling methodology, meteorological data, and results are summarized below. Detailed discussions of the dispersion modeling to determine the offsite impacts of toxic air pollutants (TAPs) emissions from the WRAP 1 stack are contained in the TBACT Document (WHC 1993).

\subsection{MODELING METHODOLOGY}

Toxic air pollutants emitted from the WRAP 1 facility were modeled to determine the maximum offsite concentration. Maximum offsite concentrations were calculated using the COMPLEX I model, onsite meteorological data, WRAP 1 stack data, and an assumed field of receptors placed along the Hanford Site boundary (WHC 1993). The results were compared to a representative ASIL for each class of TAP to demonstrate compliance with air toxic regulations.

In the case of a mixture of toxic air pollutants, compliance is demonstrated by either modeling each pollutant individually or summing them into categories and comparing the maximum ambient levels in each category to the smallest ASIL for that category (WAC 173-460-050(4)). As mentioned in the regulation, Ecology regulates two classes of toxic air pollutants. Class $A$ pollutants are suspected carcinogens and Class $B$ pollutants are acutely toxic. For this analysis, VOCs were grouped into four categories: carcinogenic volatile organic carbons (CVOCS) (Class A); noncarcinogenic volatile organic carbons (NCVOCS); CFCs (freons); and acid gases produced during VOC control.

The purpose of the four classes of TAPs is to define groups of similar pollutants with similar ASILs that could be modeled separately. So many compounds could potentially be present at WRAP 1 that it would be unjustifiable to model them individually. On the other hand, combing all of the VOCS (VOCS, NCVOCS, and CFCS) into a single group and using the smallest ASIL for the CVOCs is unrealistic because most of the emissions consist of NCVOCs that have relatively high ASILs.

The COMPLEX 1 model was used instead of other available models (ISCST or SCREEN) because it provides the most realistic prediction of the ambient concentrations. COMPLEX 1 is well suited for modeling impacts of the elevated terrain along the south and west boundaries. Neither ISCST nor SCREEN were developed to model elevated terrain. COMPLEX 1 is comparable to ISCST for modeling the flat terrain along the northern boundary. SCREEN was not used for this assessment because it is not designed to use the measured wind speed and direction data that are available for the Hanford Site.

A series of 76 receptors were assumed along the Hanford Site boundary at a horizontal spacing of approximately $2 \mathrm{~km}(1.2 \mathrm{mi})$. Maximum 24-hour and annual average off-site concentrations were determined for each receptor for a $1,000 \mathrm{gm} / \mathrm{sec}$ emission rate. The ambient concentrations for each class of compounds were then calculated by scaling the modeling results by the 
predicted emission rates. The off-site concentrations for the 76 receptors were compared, and the largest 24 -hour and annual average off-site concentrations were then used in the analysis.

\subsection{METEOROLOGICAL DATA}

The COMPLEX I model requires hourly meteorological data representative of onsite conditions. Five years of onsite meteorological data (i.e., 1986-1990) were employed to ensure the results would adequately represent worst-case dispersion conditions at the site. The meteorological data for the WRAP 1 site was collected by Battelle at the Hanford meteorological tower, located between the 200 East and 200 West Areas. The data used in the analysis include sequential hourly wind direction, wind speed, ambient temperature, mixing height, and stability class.

\subsection{MODEL RESULTS}

The estimations of the toxic substance content of the wastes and of the anticipated uncontrolled toxic air pollutant emissions were presented in Section 3.1. It was assumed that the emissions would occur 8,760 hours/year.

For the five years modeled, the maximum 24-hour concentrations occurred at $11.9 \mathrm{~km}(7.4 \mathrm{mi})$ west of the facility. The maximum annual average concentrations occurred $27.4 \mathrm{~km}$ (17 mi) east of the facility during 1987.

Maximum annual average and 24-hour average ambient concentrations were calculated for the four classes of toxic polluiants: CVOCs, NCVOCS, CFCs, and acid gases. The lowest ASIL of each class was used for comparison with the modeled concentrations:

- CVOCs - $0.040 \mu \mathrm{g} / \mathrm{m}^{3}$ for dichloroethane

- NCVOCs - $8.3 \mu \mathrm{g} / \mathrm{m}^{3}$ for tributylphosphate

- CFCs - 11,655.0 $\mu \mathrm{g} / \mathrm{m}^{3}$ for chlorodifluoromethane

- Acid Gases - $8.5 \mu \mathrm{g} / \mathrm{m}^{3}$ for HF.

The predicted maximum concentrations were compared to the appropriate ASIL in Table 4-2. The following conclusions were drawn based on the modeling results.

- The maximum fenceline concentrations caused by the uncontrolled WRAP 1 emissions are much lower than the ASILs.

- The uncontrolled CVOCs would cause an impact that is only 1.3 percent of the ASIL.

- The uncontrolled NCVOCs would cause an impact that is only 4.6 percent of the ASIL.

- The uncontrolled CFCs would cause an impact that is only 0.003 percent of the ASIL. 
Table 4-1. Maximum Toxic Air Pollutant Ambient Concentrations for the Waste Receiving and Processing Module 1 Facility Emissions.

\begin{tabular}{|l|c|c|c|c|}
\hline & \multicolumn{2}{|c|}{$\begin{array}{c}\text { Uncontrolled emissions } \\
\text { with monitoring }\end{array}$} & \multicolumn{2}{|c|}{$\begin{array}{c}\text { ASIL in } \mu \mathrm{g} / \mathrm{m}^{3} \\
\text { (minimum of the } \\
\text { class considered) }\end{array}$} \\
\hline Pollutants & $\begin{array}{c}\text { Conc } \\
\left(\mu \mathrm{g} / \mathrm{m}^{3}\right)\end{array}$ & $\begin{array}{c}\text { ASIL average } \\
\text { time }\end{array}$ & $\begin{array}{c}\text { Conc } \\
\left(\mu \mathrm{g} / \mathrm{m}^{3}\right)\end{array}$ & $\begin{array}{c}\text { ASIL average } \\
\text { time }\end{array}$ \\
\hline CVOCs & $\begin{array}{c}4.7 \times 10^{-4} \\
(1.2 \%)\end{array}$ & annual & 0.040 & annual \\
\hline NCVOCs & $\begin{array}{c}4.5 \times 10^{-1} \\
(5.4 \%)\end{array}$ & 24 -hour & 8.3 & 24 -hour \\
\hline CFCs & $\begin{array}{c}3.9 \times 10^{-1} \\
(0.003 \%)\end{array}$ & 24 -hour & $11,655.0$ & $24-$ hour \\
\hline Acid Gas & 0 & $24-$ hour & 8.5 & $24-$ hour \\
\hline
\end{tabular}

NOTES: $(1.2 \%)$ indicates percentage of ASIL.

Concentrations in $\mu \mathrm{g} / \mathrm{m}^{3}$. Modeled using Complex 1. 
DOE/RL 93-18, Rev. 0

This page intentionally left blank.

4-4 
DOE/RL 93-18, Rev. 0

\subsection{BEST AVAILABLE CONTROL TECHNOLOGY FOR TOXICS ASSESSMENT}

A Best Available Control Technology for Toxics (TBACT) assessment has been completed for the WRAP I facility (WHC 1993). Because toxic emissions from the WRAP 1 facility are sufficiently low and do not pose any health or safety concerns to the public, no controls for VOCs, and installation of HEPA filters for particulates satisfy TBACT for the facility. (Please refer to the TBACT that has been transmitted with this document.) 
DOE/RL 93-18, Rev. 0

This page intentionally left blank. 


\subsection{REFERENCES}

40 CFR 61, "National Emission Standards for Hazardous Air Pollutants," Code of Federal Regulations.

Carter, G. 1993, HEPA Filters in Series and Projected Efficiency, (telephone conversation with M. Carter, testing manager, Flanders Filters, March 8 , EBASCO, Richl and, Washington.

SAIC, 1991, Letter Report For The TRUSAF Phase I Air Sampling Task, 91-0174.AVR, Science Applications International Corporation, Richland, Washington (see WHC 1993).

WHC, 1992, WRAP Module 1 Air Emissions Source Term, WHC-SD-W026-TI-003, West inghouse Hanford Company, Richland, Washington.

WHC, 1993, WRAP Module 1 Best Available Contrrl Technology Assessment, WHC-SD-W026-TI-005, January 1993, Westinghouse Hanford Company, Richland, Washington. 
DOE/RL 93-18, Rev. 0

This page intentionally left blank. 
DOE/RL 93-18, Rev. 0

APPENDIX A

CALCULATIONS FOR EVAPORATIVE EMISSION RATES

$A-i$ 
DOE/RL 93-18, Rev. 0

This page intentionally left blank. 


\section{CALCULATIONS FOR EVAPORATIVE EMISSION RATES}

This appendix describes the methods used to calculate the average volatile organic compound evaporation emission rates at the RWM gloveboxes. Spray paint cans and sealed containers containing paint, solvents, and other free liquid will be punctured to depressurize them. It is anticipated that the free liquids will then be decanted into a holding pan, which will periodically be drained into a final sealed container for stabilization of the liquid.

It is assumed that all of the gaseous propellants (propane, butane, and Freon compounds) will be released into the ventilation air stream when the spray cans are punctured. After that, minor evaporative losses of VOCs from the paints and solvents will occur while the liquid in the holding pan is exposed to the air.

The maximum evaporation rates from the exposed liquids in the holding pan were calculated using the equations developed to simulate evaporative losses from holding ponds or accidental spills (Drivas 1982). Those equations assume that the volatilization rate is limited by gas-film mass transfer across the fluid-air interface. The governing equation is:

$$
d N_{l} / d t=\left(K_{8}\right)(A)\left(P_{l}\right)
$$

where $\mathrm{dN} / \mathrm{dt}$ is the maximum volatilization rate in gmole/hr; $K_{z}$ is the mass transfer coefficient in gmole $/ \mathrm{hr} / \mathrm{m}^{2} / \mathrm{atm} ; \mathrm{P}_{1}$ is the equilibrium vapor pressure of the individual compound in atm; and $A$ is the surface area of exposed liquid in $\mathrm{m}^{2}$.

The mass transfer coefficient $K_{z}$ is calculated based on the air speed over the exposed liquid:

$$
K_{8}=1.21\left(V^{0.78}\right)\left(D^{-0.11}\right)\left(S c^{-0.67}\right)
$$

where $\mathrm{V}$ is the air speed over the exposed liquid in $\mathrm{m} / \mathrm{hr} ; \mathrm{D}$ is the diameter of the exposed liquid surface in $\mathrm{m}$; and $\mathrm{Sc}$ is the vapor phase Schmidt Number (assumed to equal 2.2 for all of the volatile organic compounds of concern). It was assumed that the net air speed through the glovebos ss is about 5 feet per minute, which is a typical value for paint spray booths. 
For this assessment, it was assumed that the equilibrium vapor pressure of an individual volatile organic compound over the exposed liquid is governed by Raoult's Law, based on the "annual average molar fraction" of the individual volatile organic compound in all of the waste that is processed at WRAP. The vapor pressure of any specified volatile organic compound is therefore given by the equation:

$$
P_{1}=\left(P S A T_{1}\right)\left(X_{1}\right)
$$

where $P_{1}$ is the equilibrium vapor pressure of component " $i$ " in atm; PSAT $_{1}$ is the saturation vapor pressure for the pure component " $i$ "; and $X_{i}$ is the mole fraction of the component in the annual average liquid stream being processed at WRAP.

The annual average emission rate depends on the composition of the liquids being processed, on the air flowrate over the exposed liquid, and on the amount of time that the liquid is exposed before the liquid is drained into sealed containers. For this assessment, the following assumptions were used:

- The temporary holding pans are $0.5 \mathrm{~m}(1.6 \mathrm{ft})$ in diameter, and the liquid is exposed for 24 hours per day

- The ventilation air flowrate through the glovebox is 5 feet per minute

- The temperature of the liquid is $20^{\circ} \mathrm{C}$

- The gloveboxes are used for 365 days per year.

Table B-1 summarizes the calculated emission rates. The assumed total annual quantity of liquid volatile organic compounds processed through WRAP is based on previous Westinghouse Hanford estimates (WHC 1992a). The compounds indicated in the table as "propellants" are known to be pressurizing agents in nearly full spray cans, and it is assumed that 100 percent of the compound will be emitted when the spray cans are punctured. For the other compounds, the "Design Emission Rate" is the lower value of either the total estimated liquid VOC throughput or the calculated evaporative loss rate.

APP.ABACFR 
DOE/RL 93-18, Rev. 0

WHC-SD-W026-TI-005 Rev. 0

Page B-4 of B-4

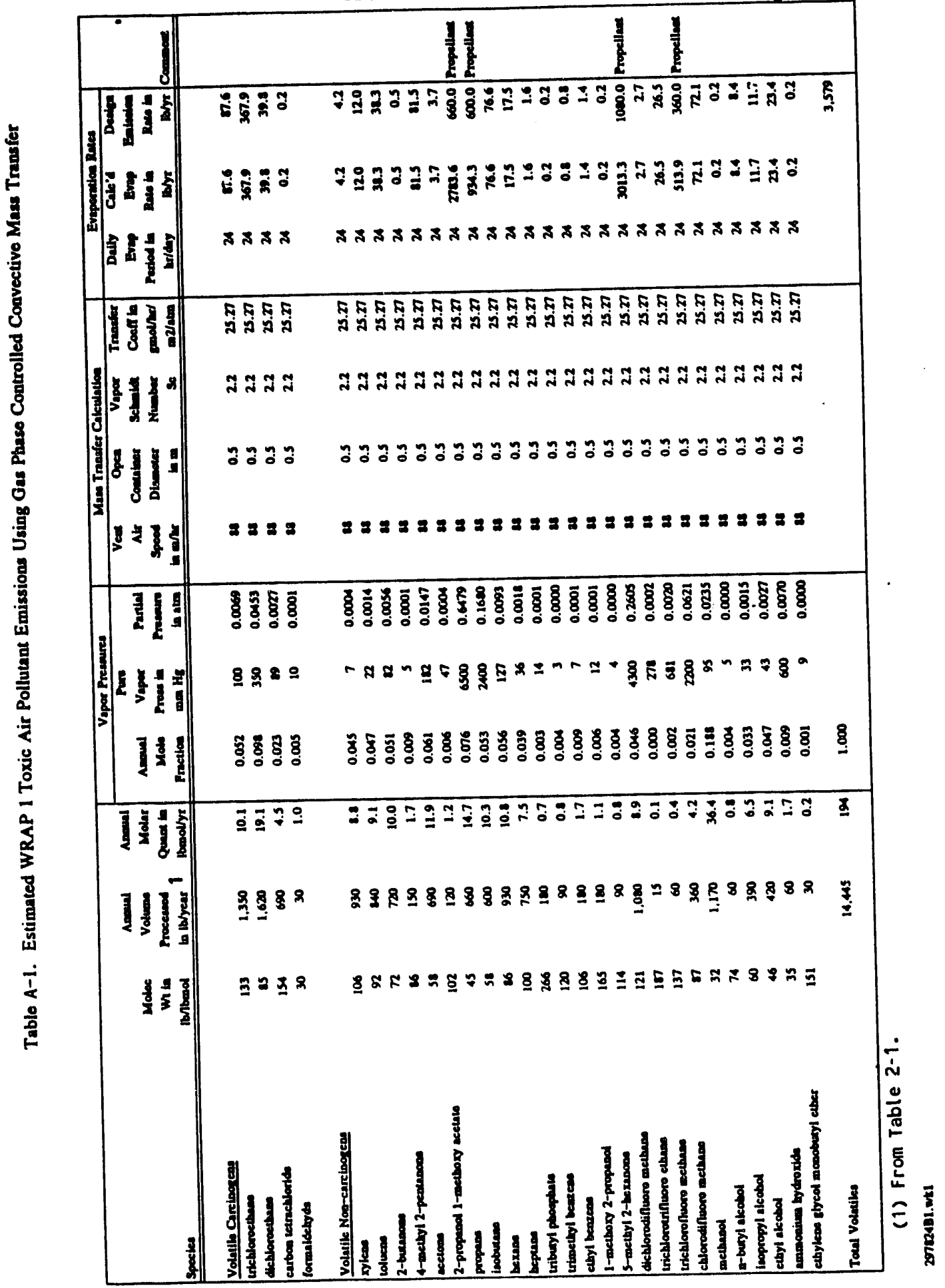


DOE/RL 93-18, Rev. 0 
DOE/RL 93-18, Rev. 0

\section{DISTRIBUTION}

Number of copies

Onsite

6

U.S. Department of Energy

Richland Field office

J. M. Augustenborg

A5-21

R. F. Guercia

A5-21

S. D. Stites

J. B. Sullivan

A5-15

Public Reading Room (2)

A5-10

1

Pacific Northwest Laboratory

Hanford Technical Library

25

Westinghouse Hanford Company

$\begin{array}{ll}\text { B. J. Broomfield } & \mathrm{N} 3-13 \\ \text { G. D. Carpenter } & \mathrm{H} 6-30 \\ \text { E. T. Coenenberg } & \mathrm{H} 6-25 \\ \text { C. J. Geier } & \mathrm{H} 6-21 \\ \text { G. W. Jackson } & \mathrm{H} 6-21 \\ \text { R. J. Landon } & \mathrm{H} 6-22 \\ \text { D. R. Lucas } & \mathrm{G} 6-46 \\ \text { P. J. Mackey } & \mathrm{B} 3-15 \\ \text { B. A. Mayancsik } & \mathrm{H} 2-58 \\ \text { R. W. Oldham } & \mathrm{H6}-25 \\ \text { T. R. Pauly } & \mathrm{G}-46 \\ \text { R. G. Pierce } & \mathrm{N} 3-13 \\ \text { J. G. Riddelle } & \mathrm{H} 2-58 \\ \text { J. G. Starkey } & \mathrm{G} 6-46 \\ \text { J. A. Swenson } & \mathrm{G} 6-46 \\ \text { T. L. Yount } & \mathrm{G} 6-46 \\ \text { Central Files } & \mathrm{L} 8-04 \\ \text { WRAP/DMC } & \mathrm{G} 6-56 \\ \text { EDMC (3) } & \mathrm{H} 4-22 \\ \text { Information Release } & \\ \text { Administration (3) } & \mathrm{H} 4-17\end{array}$

Distr-1 

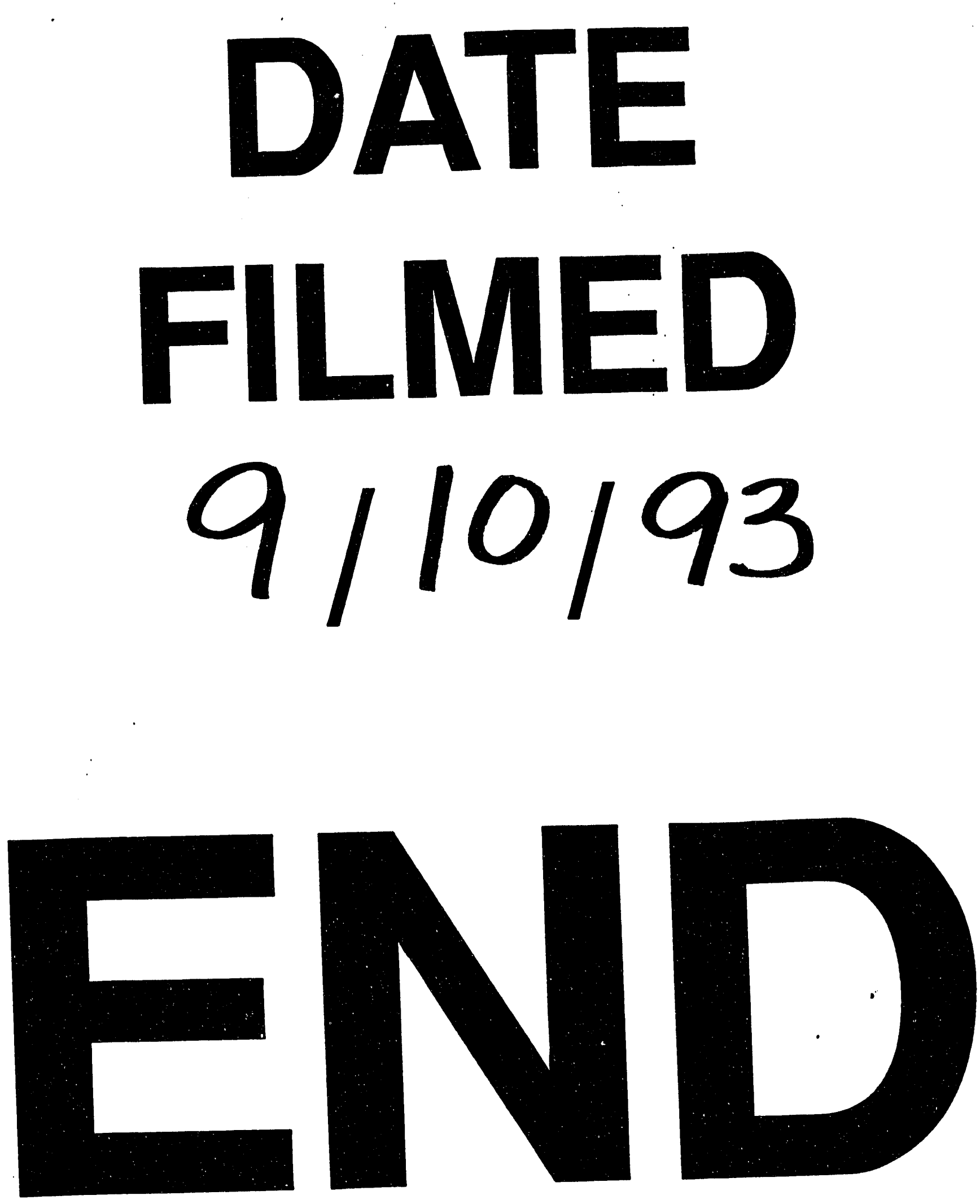
